\title{
THE USES AND ABUSES OF CONVICTIONS SET ASIDE UNDER THE FEDERAL YOUTH CORRECTIONS ACT
}

\author{
Fred C. Zacharias*
}

In 1950 Congress enacted a comprehensive alternative sentencing system for youthful offenders between the ages of eighteen and twentysix. ${ }^{1}$ As part of this Federal Youth Corrections Act (FYCA) ${ }^{2}$ Congress provided that convicted youthful offenders ${ }^{3}$ who satisfy the requirements of their sentences may have their convictions "set aside."4 Much has been written about the technical meaning of that provision, ${ }^{5}$ but little attention has been paid to its practical effect. ${ }^{6}$ This article seeks to fill that void.

Confusion arises initially from the language the 1950 Congress chose to insert into the statute. "What does "set aside" mean? Is it equivalent to "expungement?" Is it the same as sealing the records for all purposes, or for some purposes? Is it intended instead to parallel a presidential pardon, or some lesser form of executive grace? The

* B.A. 1974, Johns Hopkins University; J.D. 1977, Yale Law School; LL.M. 1981, Georgetown University Law Center, Associate, Dobrovir, Oakes \& Gebhardt, Washington, D.C.

1. Federal Youth Corrections Act, ch. 1115, 64 Stat. 1085 (1950).

2. 18 U.S.C. $\S \S 5005-5026$ (1976).

3. The Act applies to offenders convicted under federal or District of Columbia law. 18 U.S.C. $\S 5024$ (1976).

4. Id. $\$ 5021$.

5. See, eg., Harnsberger, Does the Federal Youth Corrections Act Remove the "Leper's Bell" from Rehabilitated Offenders?, 7 FLA. ST. U.L. Rev. 395 (1979); Ritz, Federal Youth Corrections Act: The Continuing Charade, 13 U. Ruch. L. REv. 743 (1979); Saperstein, Expungement for Youth Offenders, 83 CASE \& COM. 3 (1978); Schaefer, The Use of Expunged Convictions in Federal Courts, 35 FED. B.J. 107 (1976); Note, Expungement of Criminal Records Under the Federal Youth Corrections Act, 62 Iowa L. Rev. 547 (1976).

6. But see Schaefer, The Federal Youth Corrections Act: The Purposes and Uses of Vacating the Conviction, 39 FED. Probation 31, 31 (Sept. 1975), in which the author notes, without further analysis, the existing uncertainty about low and when a set-aside conviction may be used.

7. Section 5021, as amended in minor detail in 1976, provides:

(a) Upon the unconditional discharge by the Commission of a committed youth offender before the expiration of the inaximum sentence imposed upon him, the conviction shall be automatically set aside and the Commission shall issue to the youth offender a certificate to that effect.

(b) Where a youth offender has been placed on probation by the court, the court may thereafter, in its discretion, unconditionally discharge such youth offender from probation prior to the expiration of the maximum period of probation theretofore fixed by the court, which discharge shall autornatically set aside the conviction, and the court shall issue to the youth offender a certificate to that effect.

18 U.S.C. \& 5021 (1976). 
meaning of the words should, of course, determine what effect a setaside conviction is to be given im any situation. Yet the legislative history and judicial interpretation of the words obfuscate rather than clarify. ${ }^{8}$ Part I of this article briefly examines the legislative history of section 5021 of the FYCA and the judicial opinions that have interpreted it, and draws conclusions about the intended meaning of the words "set aside." Only by understanding what Congress wanted to accomplish by setting aside convictions of youthful offenders can judges and law enforcement officials determine when and how those convictions should be used after the setting-aside process is complete. ${ }^{9}$

8. American jurisdictions have used many different words to refer to reducing the effect of a prior conviction. Some of these words, such as "expungement," are well-defined. See, e.g., BLACK's Law Dictionary 522 (5th ed. 1979). ("Expungement of record. Process by which record of criminal conviction is destroyed or sealed after expiration of time"). In this article, the term "expunged" means "rendered null and unusuable for any purpose." Other terms, such as "sealimg" or "erasure" of records are defined, but may encompass a range of procedures or concepts. See, e.g., BlACK's LAW DictionaRY, supra, at 486 ("Erasure of record. . . . Within statute providing that all police and court records shall be erased upon acquittal of the accused, word 'erased' means at the very least nondisclosure") (emphasis added). Compare Doe v. Webster, 606 F.2d 1226, 1233 (D.C. Cir. 1979), with District of Columbia v. Hudson, 404 A.2d 175, 181 (D.C. Ct. App. 1979). In these cases the federal and local appellate courts within the same jurisdiction established entirely different procedures based on varying interpretations of the words "expungement" and "sealing." A third set of words, such as "set aside" and "vacate," are used synonymously but have no defined meaning whatsoever. See Schaefer, supra note 5, at 108. For a comparison of the definitions of the various terms employed to limit the effect of criminal convictions, see Kogon \& Loughery, Sealing and Expungement of Criminal Records-The Big Lie, $61 \mathrm{~J}$. CRIM. L.C. \& P.S. 378, 379-80 (1970).

The linguistic confusion is exacerbated by judicial and legislative imprecision in referring to those procedures that are well-defined. Courts interpreting statutes with ill-defined terms such as "set aside" routinely refer to them as "expunction" statutes. See, e.g., Rehman v. Immigration \& Naturalization Serv., 544 F.2d 71, 74 (2d Cir. 1976); Tatum v. United States, 310 F.2d 854, 856 n.2 (D.C. Cir. 1962). Some state statutes use defined concepts like expungement to inean something less than destruction or sealing. See, e.g., CaL. Penal Code $\$ \S 1203.4$, 1203.4(a) (West Supp. 1981). See Note, The Effect of Expungement on a Criminal Conviction, 40 S. CAI. L. Rev. 127, 132 (1967); cf. United States v. Glasgow, 389 F. Supp. 217, 225 n.21 (D.D.C. 1975) (referring to 36 state expungement statutes, some of which provide for probation even before any conviction is registered).

A full examination of statutes other than the FYCA is beyond the scope of this article. For discussions of other statutes or provisions for reducing the force of criminal convictions, see Baum, Wiping Out a Criminal or Juvenile Record, 40 CAL. ST. B.J. 816 (1965); Booth, The Expungement Myth, 38 L.A.B. BuLL. 161 (1963); Gough, The Expungement of Adjudication Records of Jivenile and Adult Offenders: A Problem of Siatus, 1966 WASH. U.L.Q. 147 (1966); Schaefer, supra note 5, at 107; Comment, Criminal Records of Arrest and Conviction: Expungement from the General Public Access, 3 CAL. W.L. Rev. 121 (1967); Note, 40 S. CAL. L. REv., supra, at 127.

9. Not all young offenders are entitled to the benefits of the FYCA. The first step toward obtaining a set-aside conviction is for the young offender to be sentenced under the FYCA to a term of probation, 18 U.S.C. $\$ 5010$ (a) (1976), or to a term of incarceration followed by a term of parole, id. $\S 5010$ (b), (c). Before imposing such a sentence the court must determine whether the defendant would benefit from treatunent under the FYCA. Id. $\S 5010$. See Dorszynski v. United States, 418 U.S. 424 (1974), and cases cited therem. For discussions of the process of making a finding of benefit, see Note, Sentencing Under the Federal Youth Corrections Act: The Need for an 
Part II of this article identifies the situations in which a set-aside conviction may assume significance. Some of these situations arise in the trial context, others do not. The common theine among them is that the former defendant would prefer the set-aside conviction to be ignored. Part II then discusses whether courts should permit the convictions to be used. This discussion, although focusing on specific situations, provides a framework of analysis generally applicable to other circumstances that may arise. The guidelines that einerge should assist future courts in determining when it is appropriate to allow set-aside convictions to resurface to the detriment of FYCA offenders, ${ }^{10}$ despite the prior judicial promise to them of a second chance in life. ${ }^{11}$

\section{The Legislative History}

\section{A. The FYCA Generally.}

The correctional system embodied in the FYCA is based on the Enghish Borstal system of corrections. ${ }^{12}$ The Borstal system came into

Explicit Finding and a Statement of Reasons, 53 B.U.L. REv. 1071 (1973); Note, Sentencing Under the Federal Youth Corrections Act: The Interpretive Confict Concerning Judicial Discretion, 23 CATH. U.L. Rev. 574 (1974); Note, Appellate Review of Federal Youth Corrections Act Sentences in the Aftermath of Dorszynski v. United States, 45 FordHAM L. REv. 110 (1976); Note, $A n$ Approach to "No Benefit" Findings Under the Federal Youth Corrections Act, 62 Iowa L. REv. 1173 (1977); Comment, Sentencing Under Section S010(D) of the Federal Youth Corrections.Act, 1974 WASH. U.L.Q. 741.

After the defendant has served a portion of his probation successfully but before it is completed, he or his probation officer may request the court to terminate the probation before the expiration of the maximum term. 18 U.S.C. \& 5021(a) (1976). A parolee may make the same request of the Parole Commission. Id. § 5021(b). If this request is honored, the court or Parole Commission "discharges" the defendant from further service of his sentence, and issues a "certifcate of discharge" to that effect. Discharge serves to set aside the conviction automatically. II. \&5021(a), (b).

As a practical matter, discharge is customarily initiated by a parole or probation officer shortly before the expiration of the sentence of any offender who has not been rearrested during the period of his probation or parole and who has complied in reasonable fashion with the conditions of his release. Once the probation or parole officer requests discharge, it is routinely granted. See United States v. Fryer, 545 F.2d 11, 13 n.3 (6th Cir. 1976) (failure to accord FYCA benefits was a "clerical error"); United States v. McCord, Civ. No. M-1487-71 (D.C. Sup. Ct. Jan. 16, 1980) (conviction set aside nunc pro tunc after expiration of sentence because the failure to set aside earher was a ministerial error); $c f$. Tatum v. United States, 310 F.2d 854, $855-56$ (D.C. Cir. 1962) (a defendant with good conduct nust be discharged and given the benefits of the FYCA).

10. The term "FYCA offender" deuotes an offender whose conviction has been set aside under the FYCA.

11. See, e.g., United States v. Purgason, 565 F.2d 1279, 1280 (4th Cir. 1977); United States v. Fryer, 545 F.2d 11, 14 (6th Cir. 1976); Mestre Morera v. Immigration \& Naturalization Serv., 462 F.2d 1030, 1032 (1st Cir. 1972); United States v. Hall, 452 F. Supp. 1008, 1010 (S.D.N.Y. 1977); United States v. Glasgow, 389 F. Supp. 217, 224 (D.D.C. 1975).

12. H.R. ReP. No. 2979, 81st Cong., 2d Sess. 1, 4, reprinted in [1950] U.S. Code ConG. SeRv. 3983, 3987. See also Dorszynski v. United States, 418 U.S. 424, 432 (1974); Umited States v. Fryer, 402 F. Supp. 831,837 (N.D. Ohio 1975), affd, 545 F.2d 11 (6th Cir. 1976). 
being at the turn of the century in response to a report on the administration of British prisons. ${ }^{13}$ The report revealed that a disproportionate number of youths aged sixteen to twenty-one passed through prison and were released unrehabilitated. A correctional systein einphasizing retraining and follow-up services for offenders of those ages was developed and proved successful. ${ }^{14}$

The Enghish precedent led Congress and the various legislative and judicial committees reporting to it to examine American crime statistics. ${ }^{15}$ The parallels were striking. American youths aged sixteen to twenty-three accounted for a highly disproportionate share of crime ${ }^{16}$ and, once having passed through the regular adult correctional system, were found to be more likely to commit other criminal acts. ${ }^{17}$ Congress resolved to establish the FYCA along the lines of the Borstal system in order to solve these problems. ${ }^{18}$

In enacting the FYCA, and particularly section 5021, Congress relied on three conclusions about young offenders. Congress believed that youths were overrepresented in the criminal population, and that

Many commentators have examined the legislative history of the FYCA at length. See, e.g., Harnsberger, supra note 5, at 402-09; Saperstein, supra note 5, at 4; Schaefer, supra note 6, at 3132; Note, supra note 5, at 557-63. It is not this article's purpose to duplicate or expand upon those examinations. The legislative history is discussed here only insofar as is necessary to understand the congressional intent underlying the provision for setting aside convictions.

13. This report is described in H.R. REP. No. 2979, supra note 12, at 4-7, reprinted in [1950] U.S. CODE CONG. SERv. 3983, 3987-89.

14. Id. 5-6, reprinted in [1950] U.S. CODE CONG. SERV. 3983, 3988.

15. Congress first expressed an interest in enacting a youth correctional system in the early 1940s. In 1941 a committee of distinguished judges inet to study the question, and in 1942 the group produced a comprehensive report recommending a system mucl like the FYCA. See Committee on Punishment for Crime of the Judicial Conference of Semior Circuit Judges, Draft of an Act Recommended by the Committee to Provide a Correctional System for Adult and Youth Offenders Convicted in Courts of the Umited States (1942), in Committee on Punishment for Crume of the Judicial Conference of Senior Circuit Judges, Report to tHe Judicial ConferENCE ON PUNISHMENT FOR CRIME 14-20 (1942). The report was transmitted to the House of Representatives the following year. Federal Corrections Act and Improvement in Parole: Hearings on H.R. 2139 and H.R. 2140 Before Subcomm. No. 3 of the House Comm. on the Judiclary, 78th Cong., 1st Sess. 1, 5-6 (1943) [hereinafter cited as Hearings on 2140]. After a three-year lull, a new but essentially identical draft of legislation was proposed in REPORT OF THE JUDICIAL CONFERENCE OF SENIOR CIRCUTT JUDGES 18-19 (1946). Finally, in 1949, the Senate held hearings featuring the judicial committee members. See Correctional System for Youth Offenders: Hearings on S. 1114 and S. 2609 Before a Subcomm. of the Senate Comm. on the Judiciary, 81st Cong., 1st Sess. 1 (1949) [hereinafter cited as Hearings on S. 1114 and S. 2609]. One year later, Congress enacted the FYCA.

16. See H.R. Rep. No. 2979, supra note 12, at 2, reprinted im [1950] U.S. Code CoNG. SERV. 3983, 3984 (citing [1949] FBI Semiannual CRIME REPORT).

17. H.R. REP. No. 2979, supra note 12, at 2, reprinted in [1950] U.S. CODE CONa. SERV. 3983, 3985.

18. $I d$. 
the overrepresentation, as in England, could not be a coincidence. ${ }^{19}$ It therefore examined reports of contemporary social scientists, and concluded that youthful offenders are markedly different in nature and character from adult offenders; Congress accepted the findings of the reports that youths undergoing the transition froin adolescence to manhood are psychologically more susceptible to antisocial conduct, but that the tendency is a temporary one. These reports reinforced Congress's views of the character of young offenders. ${ }^{20}$ Carrying the concept to its logical end, Congress determined that dealing with young offenders at an early stage was the only way to turn them from a life of habitual crime; offenders within the relevant age group were seen to be at a crossroads, with one fork leading to rehabilitation, the other to indefinite recidivism. ${ }^{21}$

Dovetailing with its determination that youthful offenders are distimctive im nature and character was Congress's second conclusion: that youths in the eighteen to twenty-six year age group ${ }^{22}$ are easier to rehabilitate than adults, but that this rehabilitation can be accomplished only by providing unique sentencing procedures and correctional facilities for them. Congress estimated that seventy percent of all youthful offenders could be "rehabilitated and made useful inembers of soci-

19. Id, reprinted in [1950] U.S. CODE CONG. SERv. 3984. Enactment of the FYCA has not reduced this overrepresentation. See, e.g., Federal Bureau of Investigation, Crime IN tHE UNITED STATES: 1976 UNIFORM CRIME REPORTS 181 (This report reveals that in 1976 persons 21 years of age and younger accounted for approximately $45 \%$ of all offenses charged). In 1950, when the FYCA was passed, crime statistics indicated that this age group was responsible for only $20 \%$ of the crimes charged. FEDERAL BUREaU of Investigation, UNIForm Crime Reports FOR THE U.S. AND ITS Possessions 110-11 (1950). See also United States v. Dancy, 510 F.2d 779, 782 n.7 (D.C. Cir. 1975) ("current statistics continue to show this disproportionality"). No statistics are available, however, regarding the current level of recidivism among defendants sentenced under the FYCA.

20. See H.R. ReP. No. 2979, supra note 12, at 2, reprinted in [1950] U.S. CodE Cong. SERV. 3983, 3984. "Sociologists and psychiatrists tell us that special causations which occur in the period between adolescence and manhood are, in a large neasure, responsible for antisocial conduct treuds manifested by persons in that age group." See also United States v. Dancy, 510 F.2d 779, 781 (D.C. Cir. 1975); United States v. Fryer, 402 F. Supp. 831 (N.D. Ohio 1975), affd, 565 F.2d 11 (6th Cir. 1976). The process by which Congress arrived at these conclusions is described in Harnsberger, supra note 5, at 402-05; Note, supra note 5, at 559-63. Although the conclusions may be correct, Cougress appears to have relied on the expertise of the semior judges who formed the committees reporting on youth corrections rather than to have sought testimony directly from the psychologists and social scientists. See note 15 supra.

21. See Dorszynski v. United States, 418 U.S. 424, $432-34$ (1974); Doe v. Webster, 606 F.2d 1226, 1233-43 (D.C. Cir. 1979); United States v. Dancy, 510 F.2d 779, 781-82 (D.C. Cir. 1975).

22. Although the British statistics were drawn fron the 16 to 21 year age group, see text following note 13 supra, and the American front the 16 to 23 year age group, see text accompanying note 16 supra, Congress chose to accord special treatinent to the 18 to 26 year age group. 
ety."23 Although the basis for this estimate does not appear in the record of the legislative proceedings, research substantiates that first offenders-who are likely to be youths ${ }^{24}$-are the least likely to commit additional crimes. ${ }^{25}$ Congress beheved that in view of these facts it would be dangerous to incarcerate or threaten to incarcerate youths in adult facilities, where hardened criminals would be able to influence them and thus reduce the likelihood of their rehabilitation. ${ }^{26}$

23. H.R. ReP. No. 2979, supra note 12, at 10, reprinted in [1950] U.S. Code CoNG. SERv. 3983, 3993. As the Supreme Court stated in Dorszynski v. United States, 418 U.S. 424 (1974): "The panoply of treatment options available under the Act is but further evidence that the YCA program was intended to be sufficiently comprehensive to deal with all but the "imcorrigible' youth." Id. at 449 (citations omitted). See also United States v. Doe, 556 F.2d 391, 392 (6th Cir. 1977) ("The purpose of the Youth Corrections Act is to enhance the probability of rehabilitation of youthful offenders"); Umited States v. Fryer, 545 F.2d 11, 13 (6th Cir. 1976) ("The Youth Corrections Act is a statute aimed at the rehabilitation of young offcnders").

24. Indeed, some proponents of the legislation as well as some courts interpreting it apparcntly assumed that the Act was directed exclnsively at first offenders. In a letter to Senator Kilgore, Judge Charles C. Wyche (W.D.S.C.), one of the bill's supporters, wrote: "I believe that a boy who makes one mistake should be permanently forgiven that mistake if his subsequent conduct imdicates that he has changed his belıavior." Hearings on $S .1114$ and $S .2609$, supra note 15, at 117. See Mestre Morera v. Immigration \& Naturalization Serv., 462 F.2d 1030, 1032 (1st Cir. 1972); United States v. Hall, 452 F. Supp. 1008, 1010 (S.D.N.Y. 1977). Nothing in the FYCA, however, limits its application to first offenders. In the author's experience, courts frequently sentence persons with juvenile or minor adult records to probation or incarceration under the FYCA.

25. In A. Nussbaum, A Second Chance, Amnesty for the First Offender 29 (1974), the author estimates that 4.5 million persons are arrested eacl year and that 1.8 million of those persons are nonrecidivists. These estimates-even granting the possibility of a substantial statistical variance-indicate that first offenders have a high potential for rehabilitation, with or without the benefits of the FYCA. Nussbaum suggests that the true recidivism rate for first offenders is somewhere between 20-25\%. Id. 82. See also Frym, The Treatment of Recidivists, 47 J. Crum. L.C. \& P.S. 1, 2 (1956) (arguing that imcarceration is counter-productive to rehabilitation); Gough, supra note 8 , at $159-62$.

26. Congress's belief no doubt stemined in part from a submission to Emanuel Celler, the Chairman of the House Judiciary Committce, in which the Deputy Attorney General espoused the separate correctional scheme partly because of the characteristics of young offenders and partly because of a felt need to separate them from older offenders:

The Director [of the Bnreau of Prisons] has stated that many of those youths 22 and 23 years of age who are convicted in Federal courts are in trouble for the first time, and experience has imdicated that they would be responsive to the flexible procedures provided by this ineasure. Also, during recent times the Bureau of Prisons has found that over 40 percent of the persons under 24 years of age presently being committed to its jurisdiction are veterans. This group, whose industrial and vocational training has been retarded because of military service, las special need for the program contemplated by the measure.

Another consideration urged by the Director of the Bureau of Prisons is that commitments in several of the previously established reformatories have been limited to persons up to 24 years of age. Such offenders are, generally speaking, too young to be committed to the ordinary penitentiaries and are the offenders who justify special efforts at rehabilitation.

It is interesting to note that the Borstal system in Great Britain, on which the proposed procedure is based to a considerable extent, originally set the age limit at 21 but that after a period of trial the age limit was raised to 23. Experience indicated the need to bring within the scope of the systein a large number of youthful offenders who other- 
With this background in mind, Congress reached its third and perhaps most controversial ${ }^{27}$ conclusion: that the purposes of the FYCA would best be served by setting aside convictions once youthful offenders completed a program of rehabilitation. ${ }^{28}$ This conclusion was based on two separate and partially mconsistent premises. First, Congress assumed that it would be appropriate to offer a reward for successful rehabilitation; 29 if the youth proved himself to be "good" by following the prescribed rules, the effect of his conviction and punishment would be minimized. Second, and perhaps more significant, Congress thought that setting aside convictions itself would help offenders to be rehabili-

wise might become repeaters through association with older and more experienced offenders.

H.R. REP. No. 2979, supra note 12, at 9, reprinted in [1950] U.S. CoDE CoNG. SERv. 3983, $3992-$ 93; see Hearings on S. 1114 and S. 2609, supra note 15, at 9 (testimony of Hon. Bolitha J. Laws (D.D.C.)). See also Dorszynski v. Umited States, 418 U.S. 424, 434 (1974).

In United States ex rel. Dancy v. Arnold, 572 F.2d 107 (3d Cir. 1978), the Court of Appeals for the Third Circuit held that no circumstances exist in which FYCA offenders can properly be incarcerated with adult offenders. This holding contradicted the conclusions of several other courts, see Abernathy v. United States, 418 F.2d 288 (5th Cir. 1969); Barr v. Umited States, 415 F. Supp. 990 (W.D. Okla. 1976); Foote v. United States, 306 F. Supp. 627 (D. Nev. 1969); Coats v. Markley, 200 F. Supp. 686 (S.D. Ind. 1962), but is consistent with the purposes underlying the FYCA. Dancy is discussed in Comment, Youth Offender Sentenced Under Federal Youth Corrections Act May Not Be Confined in the General Population of the Federal Penitentiary, 10 RUT.-CAM. L.J. 471 (1979).

27. Controversy surfaced when Senator Kilgore solicited opinions fron federal district court judges about the proposed legislation. Most judges reacted favorably. Judge John Paul of the Eastern District of Virginia, however, strongly objected to the set-aside provision, stating:

For one thing, it would restore to some vicious and dangerous persons the full rights of citizenship, involving the right to vote and to serve on juries, etc. It would also involve the question of . . . this synthetic pardon in case of future offenses. . . . I am, of course, syinpathetic with any effort to rehabilitate persons convicted of crime and to restore them to a life of good conduct, but it is my firm impression that much of the criminality of today is encouraged by the lenient treatment accorded to criminals.

Hearings on S. 1114 and S. 2609, supra note 15, at 110. See also Harnsberger, supra note 5, at 40410; Note, supra note 5, at 549.

28. Some commentators apparently assume that because Congress believed some provisions minimizing the effect of a young offender's conviction would be rehabilitative or otherwise beneficial, Congress must have intended the convictions to be expunged in their entirety. See, e.g., Harnsberger, supra note 5, at 402-09; Saperstein, supra note 5, at 4; Schaefer, supra note 6, at 3132. As discussed below, Congress may well have intended sonie lesser form of rehef. See text accompanying notes $40-42$ infra. At least three courts have held that expungement is not what Cougress wanted to accomplisl through section 5021. See United States v. Doe, 556 F.2d 391 (6th Cir. 1977); Umited States v. McMains, 540 F.2d 387 (8th Cir. 1976); United States v. Hall, 452 F. Supp. 1008 (S.D.N.Y. 1977). See also Doe v. Webster, 606 F.2d 1226 (D.C. Cir. 1979); United States v. Henderson, 482 F. Supp. 234 (D.N.J. 1979).

29. Many courts liave referred to the congressional purpose of permitting successful offenders to live free of the "taint" of a conviction. See, e.g., United States v. Purgason, 565 F.2d 1279, 1280 (4th Cir. 1977); United States v. Fryer, 545 F.2d 11, 13 (6th Cir. 1976); Mestre Morera v. Immigration \& Naturalization Serv., 462 F.2d 1030, 1032 (Ist Cir. 1972); United States v. Hall, 452 F. Supp. 1008, 1010 (S.D.N.Y. 1977); People v. Garcia, 93 Misc. 2d 667, 670, 402 N.Y.S.2d 164, 16667 (Sup. Ct. 1978). 
tated. ${ }^{30}$ A once-convicted youth would be free to become a productive member of society because he would be free of any stigma from his criminal conviction. Such, at least, was the plan. ${ }^{31}$

There remained the question of how best to effectuate these conclusions about the nature of young offenders and promote the rehabilitative purpose of the FYCA. The result was section 5021, which provided that convictions could be "set aside." It was left to the courts to determine what those words would mean.

\section{B. Section 5021 .}

The fact of a criminal conviction may arise im a variety of situations, ranging from later criminal proceedings to inquiries on employment application forms. ${ }^{32}$ If by setting aside a young offender's criminal conviction Congress meant to expunge ${ }^{33}$ all record of the conviction, then its subsequent use im any situation, civil or criminal, would be improper. If, on the other hand, Congress merely wanted to award the youth a certificate of rehabilitation to help him explam his criminal conduct, then third parties could appropriately rely on the conviction in making decisions about him. As might be expected when the political process is involved and some controversy arises, ${ }^{34}$ it appears from the legislative history that the provisions of section 5021 of the Federal Youth Corrections Act constitute a compromise between full expungement and a token statement of rehabilitation.

Proponents of section 5021 referred to its effect in a variety of

30. See Doe v. Webster, 606 F.2d 1226, 1233 n.20 (D.C. Cir. 1979):

The set-aside certificate could hardly be regarded as conceptually inconsistent with an expungement; if anything, it reinforces the conclusion that a significant event having wide-ranging consequences has occurred. The certificate has also been regarded as a symbohic token of forgiveness, trust, and confidence, thus aiding in the rehabilitation process.

See also United States v. Glasgow, 389 F. Supp. 217, 224 (D.D.C 1975) ("The Court holds that the setting aside of a conviction pursuant to 18 U.S.C. $\$ 5021(\mathrm{~b})$ is a form of treatment under the Youth Corrections Act"); 107 CoNG. REC. 8709 (1961) (testimony of Sen. Dodd) ("I think Section 5021 represents an important factor in the treatment of youthful offenders"); Note, Expungement of Criminal Convictions in Kansas: A Necessary Rehabilitative Tool, 13 WASHBURN L.J. 93 (1974).

31. Many commentators have concluded that this aspect of the FYCA has been so limited as to rob it of practical effect. See, e.g., Harnsberger, supra note 5, at 396-97; Ritz, supra note 5, at 758-59; Saperstein, supra note 5, at 4-6.

32. See text accompanying notes 71-177 infra for a discussion of these situations.

33. See note 8 supra for a definition of "expungement." For a useful discussion of what "expungement" means in practice, see Schaefer, supra note 5. See also Baum, supra note 8, at 821-28; Booth, supra note 8, at 163-65; Gough, supra note 8, at 147; Comment, Expungement in Ohio: Assimilation Into Society for the Former Criminal, 8 AKRON L. REv. 480, $490-97$ (1975); Comment, supra note 8, at 127; Note, supra note 8.

34. See note 27 supra. 
ways. Some stated that it "wip[es] out . . . the conviction."35 Others, focusing on the effect of convictions on einployinent opportunities, noted that the Act would "blot . . . out [the] sentence," leaving young offenders "without any stigma on their [lives]"36 or "stain on their records." 37 A third reference was to "restoring" a young offender's "civil rights" to him. ${ }^{38}$ Froin these statements, one commentator concluded that "there can be little doubt that [the sponsors of the bill] regarded the proposed FYCA as a bill which mandated expunction of a youth offender's criminal records." 39

It is reasonably clear, lowever, that Congress did not intend to provide for full and total expungeinent of set-aside convictions. In 1942 , in the original draft of the proposed legislation, the predecessor of section 5021 stated as follows:

Upon the conditional discharge by the [Youth] Authority of a youth offender before the expiration of six years from the date of his conviction, where an original sentence was not imposed on such youth offender, and upon the unconditional discharge by the authority of a youth offender, upon whom an original sentence was unposed, before the expiration of the original sentence, the conviction shall be automatically set aside and held for naught, and the Authority shall issue to the youth offender a certificate to that effect. ${ }^{40}$

By 1946 Congress had removed the "held for naught" language and replaced it with a provision that was less favorable to offenders than the

35. See Hearings on $S$. 1114 and $S$. 2609, supra note 15, at 70 (testimony of the Hon. Orie L. Phillips (10th Cir.)); id. 82 (testimony of James E. Palmer, President of the Federal Bar Association); $\mathscr{f}$. id. 110 (letter of the Hon. John Paul (W.D. Va.), in which Judge Paul objected to the provision that "wiped out" convictions).

36. Id. 19 (testimony of the Hon. Bolitha J. Laws (D.D.C.)).

37. Id 45 (statement of Sen. Harley Kilgore); $c f$ id. 45 (testimony of the Hon. John Parker (4th $\mathrm{Cir}$.)) (the bill would permit the whole board to "set aside [a young offender's] conviction so that he will not have a criminal record staring him in the face").

38. Id. 14 (testimony of the Hon. Bolitha J. Laws (D.D.C.)).

39. Harnsberger, supra note 5, at 408-09. Harnsberger relied on the dictionary definitions of words like "wipe out" and concluded that the bill's sponsors wanted to "obliterate" or "destroy completely" all record of a conviction. Id. 407. Other commentators have asserted without explanation or support that if Congress ineant section 5021 to have any effect, it must have intended full expungement, ie, a sealing of the records from any further access. See, e.g., Saperstein, supra note 5; Schaefer, supra note 6; Note, supra note 5. The first view is too literal a reading of imprecise legislative testimony and is belied by other parts of the legislative history. See text accompanying notes $40-47$ infra. The second view fails to acknowledge the possibility that a remedy short of full expungement might provide a young offender with substantial benefits. This partial rehef appears to be what Congress intended. See text accompanying notes 59-66 infra. See also United States v. Hall, 452 F. Supp. 1008, 1012 (S.D.N.Y. 1977) ("It cannot be argued that the Act serves hittle purpose if a defendant's record is not expunged in addition to being set aside").

40. Committee on Punishment for Crime of the Judicial Conference of Senior Circuit Judges, Proposed Drafi of an Act Recommended to Provide a Correetional System for Adult and Youth Offenders \& 13, at 19-20 (1942) (emphasis added). This report was suburitted to the House of Representatives in 1943. See Hearings on H.R. 2140, supra note 15, at 5-6. 
one eventually enacted. It stated: "In the event an offender is unconditionally discharged before six years from the date of his conviction, the conviction is automatically set aside and the offender shall be issued a certificate to this effect by the Authority, such certificate having the same effect as a pardon." 41 When Congress passed the bill in 1950 it adopted the "set aside" language standing alone. ${ }^{42}$

Thus, whatever ambiguities may exist in the legislative history, it is clear that Congress considered passing a statute providing for full expungement-the 1942 version-but rejected the proposal. Testimony by Judge Orie L. Phillips ${ }^{43} \mathrm{im}$ hearings conducted in 1949 supports the view that the 1950 version was not imtended as a full expungement statute. Judge Phillips agreed that section 5021 would "wipe out" a conviction, but also thought that the fact of the conviction imght be made known to potential employers. ${ }^{44}$ Because convictions that are expunged are ordinarily maccessible, 45 Judge Phillips's comments make sense only if the records of the convictions would not be expunged and might im some way come into the hands of employers. ${ }^{46}$

41. Report of the Judicial Conference of Senior CirCuit Judges 18-19 (1946) (emphasis added). A presidential pardon reduces the effect of a criminal conviction in only a limited fashion. See text accompanying notes 59-66 infra.

42. The "pardon" language remained a part of the legislation until 1949. See Hearings on $S$. 1114 and $S .2609$, supra note 15 , at 7,70-71.

43. Judge Phillips, then Chief Judge of the Coart of Appeals for the Tenth Circuit, was chairman of the Subcommittee on Treatment of Youthful Offenders of the Committee on Punishment of Crime, a committee of the Judicial Conference of Senior Circuit Judges (later renamed Judicial Conference of the United States). See Hearings on S. 1114 and S. 2609, supra note 15, at 59.

44. Judge Phillips testified that

the act does provide for the wiping out of the conviction if the youth is discharged. . . . The purpose of that is to help him get a job and keep him from having to be turned down by a prospective employer because of the fact that he has had a conviction. It does not entirely reinove the difficulty but he can say to the prospective employer, 'I have gone through this thing. They think I ann rehabilitated and they have given me this clearance.'

Id. 70 .

45. See Schaefer, supra note 5, at 107-08, in which the author correctly concludes that young offenders who have had their convictions set aside pursuant to the FYCA may deny the fact of their convictions to potential employers. The possibility of denial, however, does not solve the problein of whether the records themselves should be physically erased. See Gough, supra note 8, at I50-62, 168-74; Comment, supra note 8, at 124-30; of. Fite v. Retail Credit Co., 386 F. Supp. 1045 (D. Mont. 1975) (a credit reporting agency may disclose a conviction that has been set aside under the FYCA), affd, 537 F.2d 384 (9th Cir. 1976).

46. At least two commentators conclude that Judge Phillips's comments refer merely to the community's knowledge of a young offender's prior conviction, which cannot be erased. See Harnsberger, supra note 5, at 407; Note, supra note 5, at 562 n.121. Although such an interpretation is plausible, patticularly where offenders from small, close-knit communities are concerned, Judge Phillips's testimony does not appear to be directed at isolated occurrences. Since most offenders live in urban areas, it is unlikely that this problem of a potential employer personally remeunbering an applicant's conviction will arise in the ordinary case. It seems nore likely that Judge Phillips was referring to the possibility that an employer may obtain access to a non- 
One other feature of the statutory language indicates that Congress did not intend to provide for expungernent. Congress chose not to use the word "expungement," though it could easily have done so. Although that term inay not have been as universally understood in 1950 as it is today, 47 Congress had before it in the 1942 draft the "held for naught" language, in addition to the term "set aside," which would have removed any questions about the provision's ineaning. It is disingenuous to assume that "set aside" was intended as a conteinporary synonym for "expunge" when Congress rejected additional language that would have had precisely that ineaning.

In recent years, several courts have considered the ineaning of section 5021 uniformly concluding that the FYCA does not provide for full expungement. ${ }^{48}$ Before the question was squarely raised, a few courts suggested in dictum that expungement was available to youth offenders. ${ }^{49}$ Other courts determined in a conclusory fashion that expungeunent was not available. ${ }^{50}$ Finally, in United States v. McMains ${ }^{51}$ the Court of Appeals for the Eighth Circuit addressed the issue in detail.

In McMains a young offender whose conviction had been set aside under the FYCA brought a civil action seeking expungement of his records. In a lengthy opinion the court vacated the district court's grant of relief, holding:

[T] he Act does not authorize expunction of the record of a conviction which has been set aside pursuant to section 5021. First, the language of section 5021 does not plainly provide for record expunction.

expunged record of the conviction. This view of Judge Phillips's testimony was adopted by the Court of Appeals for the Eighth Circuit in United States v. McMains, 540 F.2d 387 (8th Cir. 1976).

47. The term "expungeineut" apparently first began to achieve wide currency in connection with state statutes regulating the use of juvenile convictions. Most of these statutes were passed after 1960. See Gough, supra note 8, at 168 n.97. Black's Law Dictionary did not include a definition of "expungeinent" until the 1979 edition. See note 8 supra.

48. See Doe v. Webster, 606 F.2d 1226 (D.C. Cir. 1979), and United States v. Henderson, 482 F. Supp. 234 (D.N.J. 1979), in which the courts issued inandates entitled "expungenent" orders, but in fact did not determine that full expungement was appropriate. See text accoinpanying notes 55-58 infra.

49. See, e.g., Brager v. United States, 527 F.2d 895, 897 n.1 (8th Cir. 1975); United States v. Mollett, 510 F.2d 625, 628 (9th Cir. 1975); Mestre Morera v. Immigration \& Naturalization Serv., 462 F.2d 1030, 1032 (1st Cir. 1972); Tatum v. United States, 310 F.2d 854, 856 (D.C. Cir. 1962); United States v. Fryer, 402 F. Supp. 831,837 (N.D. Ohio 1975), aff'd, 545 F.2d 11 (6th Cir. 1976).

50. See, e.g., United States v. Doe, 556 F.2d 391 (6th Cir. 1977), and Fite v. Retail Credit Co., 386 F. Supp. 1045 (D. Mont. 1975), affd, 537 F.2d 384 (9th Cir. 1976), in which the expungennent issue was directly raised. Cf. United States v. Klusman, 607 F.2d 1331, 1334 (10th Cir. 1979) (expungennent is not available nnder the FYCA) (dictum); United States v. Canniff, 521 F.2d 565, $569 \mathrm{n} .2$ (2d Cir. 1975) (the record of a set-aside conviction is "not kept sealed") (dictum), cert. denied, 423 U.S. 1059 (1976).

51. 540 F.2d 387 (8th Cir. 1976). 
We are confident that had Congress intended to authorize expunction, it would have manifested that intent with far greater clarity. It has done so on other occasions. See 21 U.S.C. $§ 844$ (b)(2). Second, the fact that section 5021 provides for the issuance of a certificate to the offender upon the setting aside of his conviction militates against a construction favoring expunction. Had Congress imtended to provide for complete eradication of the offender's criminal record, such a certificate would seem unnecessary. Third, it would be incongruous to infer a statutory right to expunge a conviction when there is no statutory right, in inost cases, to expunge the record of an arrest that does not result in a prosecution. ${ }^{52}$

The court thus approved the practice of law-enforcement authorities of retaining records of set-aside convictions with merely a notation on the records that the defendant has been discharged.

Although the McMains decision has been bitterly attacked, ${ }^{53}$ with some justification, ${ }^{54}$ its reasoning is essentially sound. But McMains does fail to recognize that even if Congress did not enact section 5021 as a full expungement statute, it nevertheless intended to accord substantial benefits to young offenders who comply with its provisions. By permitting law-enforcement authorities simply to note the words "set aside" on the conviction records and to disseininate the records as widely as before, the court withdrew from youth offenders most of the benefits the FYCA's proponents wanted them to have.

A recent decision of the Court of Appeals for the District of Columbia Circuit, Doe v. Webster, ${ }^{55}$ does not suffer from this failing. In Doe, as im McMains, an offender whose conviction had been set aside

52. Id. at 389. See also United States v. Hall, 452 F. Supp. 1008 (S.D.N.Y. 1977); United States v. Heller, 435 F. Supp. 955 (N.D. Ohio 1976) (closely tracking the McMains decision). at 547 .

53. See, e.g., Ritz, supra note 5, at 758-59; Saperstein, supra note 5, at 6; Note, supra note 5,

54. The McMains court attempted to bolster its position by relying on questionable arguments. For example, it argued that if Congress had wanted to expunge convictions, there would be no need to issue certificates of discharge. $540 \mathrm{~F} .2 \mathrm{~d}$ at 389 . This conclusion iguores the possibility that an offender might at some time need to prove that his conviction has been set aside to someone (e.g., a potential employer) who knows of the conviction but not of the subsequent discharge.

Similarly, the eourt's reference to 21 U.S.C. $\$ 844$ (b)(2) (1970) as proof that Congress knew the term "expungement," 540 F.2d at 389, overlooks the fact that section 844(b)(2) was enacted in 1970, Pub. L. No. 91-513, title II, Part D, § 404, 84 Stat. 852 (1970), twenty years after the enactment of the FYCA; by 1970 expungement had become a universally employed term. See note 47 supra. Despite this faulty reasoning, however, the court's conclusion that Cougress would have been more precise had it intended to provide for expungement is sound. See text accoinpanying notes 40-47 supra.

55. 606 F.2d 1226 (D.C. Cir. 1979). See also United States v. Henderson, 482 F. Supp. 234 (D.N.J. 1979) (extending Doe's reasoning to arrest records relating to subsequently set-aside convictions), discussed in note 57 infra. Doe is discussed extensively in Note, The Expunction of Criminal Records Under the Federal Youth Corrections Act: A Novel Judicial Interpretation, 26 WAYNE L. REV. 1111 (1980). 
sought total expungement and physical destruction of his records. The district court demed rehef. The court of appeals, im a scholarly opmion, examined the FYCA's legislative history, determined that $\mathrm{Mc}$ Mains had failed to preserve adequately the strong rehabilitative purposes of the Act, ${ }^{56}$ and reversed the lower court decision. Recognizing that mere notation of the words "set aside" on the records would be of only limited assistance to offenders, the court ordered the Federal Bureau of Investigation to collect all set-aside records im a central storage facility and not to refer to them except in the course of a bona fide criminal imvestigation or by special court order. ${ }^{57}$ The court also ordered the government to respond in the negative when asked if an offender had a prior conviction. 58

The legislative history and the McMains and Doe opinions therefore establish that section 5021 is not a full expungement statute and does not foreclose completely the use of a set-aside conviction. On the other hand, the legislative history also reveals that Congress did want to give FYCA offenders substantial benefits. Congress specifically rejected the proposed legislation of 1946 that would have limited the effect of the setting-aside process to that of a presidential pardon. ${ }^{59}$ As

56. 606 F.2d at $1233-41$.

57. Id. at 1244. Unfortunately the court added confusion to the "set aside" issue by referring to its order as one of "expungement." See id. at 1243. In fact, it was nothing of the sort; the court did not order the record of the convictions to be erased or sealed for all purposes, despite the court's statement that the records were not to be used for "any other purpose," id. at 1244.

The decision not to require the records in Doe to be sealed left the arrest records accessible; questions can thus later arise about the disposition of the arrest. One district court has noted this problem with the Doe ruling, see United States v. Henderson, 482 F. Supp. 234, 241-43 (D.N.J. 1979), and solved it by requiring the offender's arrest records to be sealed, id. at 242-43. Arguably, the problem arises not from any oversight by the Doe court but fronl the language of section 5021, which refers only to records of convictions. Perhaps this is what Judge Phillips had in mind at the time of the FYCA's enactment when he anticipated that offenders with set-aside convictions might nonetheless be forced to respond to questions about their criminal records. See text accompanying notes 44-46 supra.

58. 606 F.2d at 1244. By explicitly ruling that it is appropriate to balance other interests against an offender's interest in nondisclosure, id. at 1245 , the court preserved the possibility that interests other than law enforcement might control in particular circumstances. The court did not foreclose an expansive definition of those "law enforcement purposes"-a definition that would permit nse of the set-aside conviction in a wide variety of situations-but it suggested that extensive use of set-aside convictions was inappropriate by stating that the records should not be used "for any other purpose," id. at 1244, without leave of the court.

59. Sce text accompanying notes 41-42 supra. One commentator has suggested that Congress rejected the pardon provision because it believed the provision interfered with the clemency power of the executive branch, rather than because Congress wished a different form of rehef for young offenders. See Schaefer, supra note 6, at 32. Schaefer, however, cites no support for that conclusion. Because a rephrasing of the provision could easily have avoided the problem, it appears unlikely that Congress sought to accomplish the effect of a pardon by using the vaguer "set aside" language. Courts imterpreting the FYCA have been unanimous in concluding that section 5021 was intended to provide a greater measure of relief than a presidential pardon. See, e.g., Mestre 
ultimately enacted, the relief embodied in section 5021 differs from a pardon in a critical respect: a pardon does not affect the fact of conviction; it forgives a defendant while reaffirming his guilt. A person receiving a pardon must first accept it, thus acknowledging his responsibility for the crime. ${ }^{60}$ Once the pardon is accepted, it operates merely to prevent any further punishment or disabilities froin accruing ${ }^{61}$ and to relieve the offender of a limited nunvber of disabilities to which he may already liave been subjected. ${ }^{62}$ But the fact of the conviction and the disabilities arising from it remain. ${ }^{63}$ In contrast, even if a set-aside conviction is not sealed, it is at least limited in its effect. Although guilt may persist, the conviction is not reaffirmcd nor can it be treated as continuing. ${ }^{64}$ Whether as a reward for rehabilitation or as part of an ongoing rehabilitative system, ${ }^{65}$ Congress clearly intended the setting-aside process to confer benefits on a young offender beyond those granted pardoned defendants. ${ }^{66}$

The paraineters of how and when a set-aside conviction may be

Morera v. Immigration \& Naturalization Serv., 462 F.2d 1030, 1032 (1st Cir. 1972); Tatum v. United States, 310 F.2d 854, 856 n.2 (D.C. Cir. 1962); United States v. Hall, 452 F. Supp. 1008, 1012 (S.D.N.Y. 1977); United States v. Fryer, 402 F. Supp. 831, 834-37 (N.D. Ohio 1975), aff.d, 545 F.2d 11 (6th Cir. 1976).

60. Burdick v. United States, 236 U.S. 79, 91 (1915).

61. See Knote v. United States, 95 U.S. 149 (1877); Lyons v. Goldstein, 290 N.Y. 19, 47 N.E.2d 425 (1943).

62. For full discussions of the scope of presidential pardons, see Baum, supra note 8, at 817 . 21 (comparing pardons to California "expungeinent"); Lavinsky, Executive Clemency: Study of a Decisional Problem Arising in the Terminal Stages of the Criminal Process, 42 CHI.-KENT L. REv. 13 (1965) (distinguishing pardons from clemency); Weihofen, Pardon: An Extraordinary Remedy, 12 RockY MTN. L. REv. 112 (1939) (describing the purposes of pardons); Weihofen, The Effect of a Pardon, 88 U. PA. L. REv. 177 (1939) (describing the effect of pardons). See also Project, The Collateral Consequences of a Criminal Conviction, 23 VAND. L. REv. 929, 1144-47 (1970) (discussing the effect of pardons on particular types of disabilities), and the sources cited in Doe v. Webster, 606 F.2d 1226, 1239 n.51 (D.C. Cir. 1979).

For articles comparing the effect of pardons to the effect of setting aside a conviction under section 5021 of the FYCA, see Schaefer, supra note 5, at 115-16; Schaefer, supra note 6, at 32; Note, supra note 5, at 557-62.

63. See, e.g., Carlesi v. New York, 233 U.S. 51 (1914) (a pardoned conviction may be a "prior conviction" for purposes of sentencing under a recidivist statute); Knote v. United States, 95 U.S. 149 (1877) (pardon does not entitle one to the proceeds of property sold under Confiscation Act of 1862). See Gough, supra note 8, at 150, and cases cited therein.

64. See United States v. Fryer, 402 F. Supp. 831 (N.D. Ohio 1975), affd, 545 F.2d 11 (6th Cir. 1976), in which the court rejected the Government's argument that a set-aside conviction could provide a basis for conviction under a statute that includes as an element a prior felony conviction. The court chastised the Government for arguing that section 5021 provided a remedy in the nature of a presidential pardon. See also Mestre Morera v. Immigration \& Naturalization Serv., 462 F.2d 1030 (1st Cir. 1972); Tatum v. United States, 310 F.2d 854 (D.C. Cir. 1962); United States v. Glasgow, 389 F. Supp. 217 (D.D.C. 1975).

65. See text accompanying notes 29-31 supra.

66. See note 59 supra. 
used therefore are set. Even Doe v. Webster ${ }^{67}$ and United States.v. Henderson, ${ }^{68}$ the most liberal decisions limiting the effect of sucl1 a conviction, deem full expungement to be mappropriate. These decisions recognize that some imterests, sucl1 as the need for law-enforcement agencies to be able to mvestigate, may at times override the purposes of the FYCA. ${ }^{69}$

On the other hand, Congress wanted to confer substantial benefits on rehabilitated offenders. ${ }^{70}$ Under no circumstances should a setaside conviction be used to the detriment of an offender more extensively than a pardoned conviction, and in most cases it should be used less extensively. Within these parameters, lowever, Congress left it to the courts to decide on a case-by-case basis whether to authorize use of the convictions-wliether the convictions be centrally stored, as ordered in Doe, or left in the hands of law-enforcement agencies, as ordered in McMains. Courts must thus balance the purposes and interests served by section 5021 and the FYCA generally as well as the societal imterests invoked to justify use of the offender's records. The following sections of this article analyze this balancing process.

\section{The Use of Set-Aside Convictions}

In the typical case, an offender trying to prevent the use of his criminal records argues that no reference may be made to his conviction because, l1aving been set aside, it no longer exists, and because Congress has forgiven him for the acts underlying it. The other party logically responds that "history cannot be rewritten;"71 wliatever subsequent events may liave occurred, the youth was convicted. Thus, the argument goes, to the extent that the fact of conviction would be relevant, it remains so despite the discliarge order. This dispute arises in a variety of circumstances. ${ }^{72}$

67. 606 F.2d 1226 (D.C. Cir. 1979).

68. 482 F. Supp. 234 (D.N.J. 1979). See the discussion in note 57 supra.

69. See also Uinted States v. McMains, 540 F.2d 387 (8th Cir. 1976), and United States v. Hall, 452 F. Supp. 1008 (S.D.N.Y. 1977), in which the courts specifically held that the government's need for full record-keeping outweighed any interest of the young offender in expungement. The court in Doe apparently shared this view.

70. See text accompanying notes 59-66 supra.

71. See, eg., Fite v. Retail Credit Co., 386 F. Supp. 1045, 1048 (D. Mont. 1975) ("The court record, regardless of the form of the judgment, reflected a fact, ie, the admission of a theft"), affd, 537 F.2d 384 (9th Cir. 1976).

72. An examination of each civil or social disability that an offender may suffer is beyond the scope of this article. See Project, supra note 62, for a comprehensive listing of these disabilities. See also Note, The Effect of State Statutes on the Civil Rights of Convicts, 47 Minn. L. REv. 835 (1963); Note, Restoration of the Civil Rights of Convicted Criminals, 1951 WIs. L. REv. 378, 379-83. 


\section{A. Recidivist Statutes.}

Most jurisdictions have statutes providing for increased punishinent of persons convicted of second and subsequent crimes. ${ }^{73}$ The statutes, generally called "recidivist statutes," take one of three forms. The first kind, known as "enhancement" statutes, either include a "prior felony conviction" as an elennent of a new crime or provide for sentences with higher maximum penalties upon proof by the prosecution of a prior conviction. "Repeat offender" statutes, a more limited form of enhancement statute, provide for increased punishment (usually by multiplying the first offense punishment by a fixed factor, depending upon the number of prior offenses) for a defendant who has committed the same type of crime in the past. These statutes are usually directed at the "career criminal," who tends repeatedly to commit crimes in one particular category. The third type of statute takes a shightly different form. It includes as an element of the crime the defendant's denial of a past conviction in connection with some otherwise lawful act, such as the apphication for permission to carry a firearm. This form of statute is designed to prevent an offender front avoiding any civil disabilities that attach to his conviction, such as prohibition of firearm possession, merely by denying the fact of the prior offense. ${ }^{74}$

Most courts considerimg the issue have agreed in primciple that setaside convictions should not provide a basis for enhanced punishment under any of these statutes. ${ }^{75}$ That view is consistent with the statutory langnage and the legislative history of the FYCA. All recidivist statutes are predicated upon the existence of a prior conviction. Even if Congress intended set-aside convictions to be given some effect ${ }^{76}$ (that

But by discussing several discrete circumstances in which set-aside convictions have surfaced, this article provides an analysis that will be generally apphicable to other similar situations.

73. For a compilation of state recidivist statutes, see Note, $A$ Closer Look at Habitual Criminal Statutes: Brown v. Parratt and Martin v. Parratt, A Case Study of the Nebraska Law, 16 AM. CRIM. L. REv. 275, 275-76 n.2 (1978). For discussions of recidivist statutes generally, see Note, The Constitutional Infirmities of Indiana's Habitual Offender Statute, 13 IND. L. Rev. 597 (1980); Note, The Habitual Criminal Act: Quantity of Convictions Only?, 59 NEB. L. RÉv. 507 (1980).

74. Some jurisdictions employ all three statutory forms in varying situations. In the District of Columbia, for example, a person convicted of an armed felony who is subsequently convicted of a violent crime is subject to a penalty of life imprisoument with a minimum of five years incarceration. D.C. CODE ANN. $\$ 22-3202$ (1973). A person who commits any nontraffic criminal offense for a second time is subject to one and one-half times the maximum term of imprisoument for the original crime and, if he commits a third similar offense, is subject to trebled penalties. Id. $\$ 22-104$. Felony offenders in the District of Columbia are also barred from possessing firearms. Id. $\S 22-3203$.

75. See, e.g., United States v. Purgason, 565 F.2d 1279, 1280 (4th Cir. 1977); United States v. Fryer, 545 F.2d 11, 13 (6th Cir. 1976); People v. Garcia, 93 Misc. 2d 667, 670, 402 N.Y.S.2d 164, 166-67 (Sup. Ct. 1978).

76. See text accompanying notes $40-46$ supra. 
is, not just "held for naught"), a court would clearly be wrong to hold that they should be treated no differently from standing convictions. That, of course, is what would happen if a set-aside conviction were invoked to trigger a recidivist statute. Furthermore, the sponsors of the FYCA made clear throughout the legislative discussions of the bill that the FYCA was intended to free an offender of the stigma and taint of his conviction. ${ }^{77}$ Surely Congress would have considered a new conviction or mcreased punishment based on prior crimes to be such a taint.

In United States v. Fryer, ${ }^{78}$ the District Court for the Northern District of Ohio confronted this issue. A defendant pleaded guilty to a federal firearms charge predicated on his false denial of a prior conviction. Subsequently, realizing that his prior conviction had been set aside under the FYCA,79 he noved to vacate his plea. The court phrased the issue as follows:

[T]he Government's argument has merit if the provisions of $\S 5021$ are im the nature of a presidential pardon. A pardon is an exceptional and specific act of grace. . . . It "remits punishment and renoves some disabilities, but does not erase the legal event determinative of the offender's status qua offender, i.e., the conviction itself. ..."

[But] if the effect of $\S 5021$ is to eliminate the youth's status as a convicted felon and to restore him to the position he held before the commission of the crime, then it seems clear that he would not fall withm the ambit of [18 U.S.C.] $\S 1202$ (a) simce the prior conviction and all its pendent liabilities have been removed. ${ }^{80}$

77. See text acconpanying notes 35-39 supra. See also United States v. Purgason, 565 F.2d 1279, 1280 (4th Cir. 1977); Mestre Morera v. Immigration \& Naturalization Serv., 462 F.2d 1030, 1032 (Ist Cir. 1972); United States v. Glasgow, 389 F. Supp. 217, 224 (D.D.C. 1975).

78. 402 F. Supp. 831 (N.D. Ohio 1975), affd, 545 F.2d 11 (6th Cir. 1976).

79. The trial conrt treated the facts of the case as described in the text. The case on appeal, however, reveals that the situation was nore complicated. Only after the defendant pleaded guilty did his attorney learn that his prior sentence had been under the FYCA. The defendant's criminal records did not reflect that fact. The attorney filed a notion in the District Conrt for the Eastern District of California for nodification of the records. That court not only inade the necessary corrections, but also ordered the defendant's discharge from probation to be retroactive to a time before the termination of the defendant's sentence. By legal fiat, therefore, the offender's conviction was automatically set aside "prior" to the new offense. See United States v. Fryer, 545 F.2d 11, 13 (6th Cir. 1976).

80. 402 F. Supp. at 834 (citations omitted). The Government argued in Fryer that the statute at issue, 18 U.S.C. app. $§ 1202$ (a) (1970), expressly provided that pardoned convictions could not become the basis for recidivist treatment. The government argued that if the statute intended to exempt set-aside convictions as well, it would have done so explicitly. The court rejected this argument by determining that a conviction set aside and therefore "non-existent" cannot logically be compared to a pardoned but contimuing conviction. As discussed in the text acconpanying notes 59-66 supra, the court could easily have reaclied the same result by deciding that a set-aside conviction must be inore circumspectly used than a pardoned conviction. 
The court concluded that the legislative intent was to erase the effect of the conviction, and ordered withdrawal of the plea and disinissal of the charges.

The Government appealed the district court's order, claiming the court had improperly treated section 5021 as an expungement statute. In a brief opimion, the Court of Appeals for the Sixth Circuit rejected the argument and affirmed the district court's order, finding that as the defendant "did not have [a] prior felony conviction" and "was not in fact a convicted felon," he had violated no law. ${ }^{81}$ Although not agreeing with the lower court's reading of the legislative history in all respects, ${ }^{82}$ the court of appeals held that Congress did intend to relieve FYCA offenders ${ }^{83}$ from treatment as recidivists.

At least one commentator has disapproved strongly of the reasoning of the two Fryer courts. ${ }^{84}$ The basis for the disapproval appears to be that the setting aside of a conviction is predicated primarily on the offender's rehabilitation; the offender's commission of a second crime shows that he is not rehabilitated and therefore should forfeit the benefits of the FYCA. ${ }^{85}$

Though this syllogism is credible, particularly in view of Congress's realization in 1950 that at best only seventy percent of all FYCA offenders would be rehabilitated, ${ }^{86}$ there is no support for it in the legislative history. Congress was aware that FYCA offenders might prove unworthy of a set-aside sentence after the termination of the sentence. It conld easily have provided for the set-aside determination to be

\footnotetext{
81. 545 F.2d 11, 13 (6th Cir. 1976).

82. See, e.g., id. at 13-14.

83. See note 10 supra.

84. See Ritz, supra note 5, at 759:

It would be an extraordinary perversion of the original purposes of the YCA if the "no prior felony conviction" theory of these cases [Fryer and United States v. Purgason, 565 F.2d 1279 (4th Cir. 1977)] should be extended to the recidivist, so that the two-time offender, whose first conviction has been set aside, cannot be convicted as a second offender.
}

See also Note, supra note 8, at 136 (arguing that the public interest in prohibiting potentially dangerous persous from having access to firearms should outweigh even a policy of full expungement).

85. This reasoning, of course, does not apply when the recidivist statute, e.g., 18 U.S.C. app. $\S 1202$ (a) (1970), is one punishing failure to acknowledge a prior conviction. If a young offender is to be relieved of the stigma associated with his conviction, as Congress intended, he must be permitted to deny the conviction if asked about it. See Schaefer, supra note 6, at 33-34. Any other practice would place him in the dilemma of choosing to be penalized for his conviction or to be penalized for denying it. The courts in Doe v. Webster, 606 F.2d 1226, 1239-41, 1244 (D.C. Cir. 1979), and United States v. Henderson, 482 F. Supp. 234, 244 (D.N.J. 1979), explicitly held that an offender may deny the existence of a set-aside conviction. Such a denial, of course, in no way shows the offender to be unrehabilitated or unworthy of the benefits of the FYCA.

86. H.R. REP. No. 2979, supra note 12, at 10, reprinted in [1950] U.S. CODE CoNa. SERv. $3983,3993$. 
made at some time thereafter. ${ }^{87}$ Yet Congress chose not to do so, relying instead on the discretion of the judges and parole authorities to determine which offenders are not worthy of relief. ${ }^{88}$ In making that determination Congress considered the ongoing rehabilitative effect of the discharge process itself, ${ }^{89}$ and apparently determined that this rehabilitative effect outweighs society's interest in using the conviction to enhance punishment if the offender sins again. Thus, Congress did not provide for subsequent use of the conviction-as it could easily have done-but rather determined that in the proper circumstances a conviction should be wholly set aside. The Fryer courts correctly held, then, that set-aside convictions should not provide the basis for enhanced punishment under recidivist statutes. ${ }^{90}$

87. Some state statutes provide for expungement upon application of the offender a specified number of years after completion of the sentence. See, e.g., 41 Mich. CoMp. LAws ANN. $\S 780.621$ (1968); 2C N.J. STAT. ANN. § 52-2 (West 1980).

88. Although some courts treat the issue of whether to set aside the conviction of a young offender who lias not violated the conditions of his probation or parole as a ministerial matter, section 5021 by its terms affords the authorities discretion not to set a conviction aside. See note 7 supra.

89. See text accompanying notes 30-31 supra.

90. Situations may arise that make application of this rule difficult because of the relative timing of the setting-aside of the conviction, the second crime, and the second conviction. The courts lrave unanimously held that the "mere possibility" that a conviction will be set aside does not suffice to prevent application of a recidivist statute. See, e.g., United States v. Vice, 562 F.2d 1004, 1005 (5th Cir. 1977), cert. denied, 435 U.S. 951 (1978); State v. Pacheco, 121 Ariz. 88, 90-91, 588 P.2d 830, 832-33 (1978); People v. Loomis, 231 Cal. App. 2d 594, 596, 42 Cal. Rptr. 124, 126 (1965); Perrin v. State, 198 Kan. 650, 653, 426 P.2d 39, 42 (1967). Although this rule might not be appropriate where other consequences of the FYCA are involved, see text accoinpanying notes 171-77 infra, it seems correct in the recidivist context. If the offender lras committed a second crime before the termination of his sentence under the FYCA, a sentencing judge or parole authority would not likely find the offender sufficiently rehabilitated to merit section 5021 treatunent. A rule based on this general premise seems appropriate. If the recidivist statute is one that punislres the denial of a conviction, see text accompanying notes 73-74 supra, its application to an offender denymg a not yet set-aside conviction is also proper, for such an offender lias not yet shown himself to be rehabilitated and therefore different froin any other offender. Thus the bencfits that the statute seeks to deny other offenders (e.g., the right to possess firearms) are correctly denied to him. See State v. Paclieco, 121 Ariz. 88, 90-91, 588 P.2d 830, 833 (1978). See also Perrin v. State, 198 Kan. 650, 653, 426 P.2d 39, 42 (1967).

A more complex problem arises when the second crime occurs before the first conviction is set aside, but the second conviction occurs after the setting aside. In this situation the authority supervising the initial sentence has determined that, despite the pendency of a new charge, the offender is rehabilitated and deserves to lrave his sentence set aside. If the recidivist statute in question is one that punisles a second conviction, it slould not be applied. At the time of the "second" conviction, the first conviction no longer exists, so it is inappropriate to treat the defendant as a second offender. See United States v. Fryer, 545 F.2d 11 (6th Cir. 1976), which, upon close reading, presents precisely this situation. See note 79 supra. In People v. Loomis, $231 \mathrm{Cal}$ App. 2d 594, 42 Cal. Rptr. 124 (1965), however, the court leld without explanation that "appellant's status at the time he possessed the gun is the critical issue." Id. at 596, 42 Cal. Rptr. at 126.

If the recidivist statute punislies a denial of the conviction, lowever, this reasoning does not apply. When an offender has denied the fact of his conviction before it has been set aside, he 


\section{B. Pretrial Diversion Programs.}

The admission of an FYCA offender to a pretrial diversion program raises almost the same issues as punishment under a recidivist statute, but demands a different result. Pretrial diversion is

a formalized procedure authorized by legislation, court rule, or, most commonly, by informal prosecutorial consent, whereby persons who are accused of certain criminal offenses and meet preestablislied criteria have their prosecution suspended for a three montl. . . . period and are placed in a community-based reliabilitation program. The rehabilitation program may include counseling, training, and job placement. If conditions of the diversion referral are satisfied, the prosecution may be nolle prossed or the case dismissed; if not, the accused is returned for normal criminal processing. ${ }^{91}$

The criteria for admission into diversion programs vary from jurisdiction to jurisdiction. Although guidelines are typically available,92

seeks to obtain a benefit to which he is not entitled or to avoid a disability he deserves. Because the element of the offense is the denial, not the conviction, invoking the recidivist statute would neither be inequitible nor contrary to the legislative intent. See United States v. Vice, 562 F.2d 1004 (5th Cir. 1977), cert. denied, 435 U.S. 951 (1978).

One final sequence remains to be discussed: where the second crime and conviction have taken place, the recidivist statute has been applied, and the prior FYCA conviction is subsequently set aside. The small likelihood of this situation arising, discussed above, explains the absence of any applicable case. Although there are cases lolding that a successful appeal of a prior conviction will not negate the imterim application of a recidivist statute, a similar result for set-aside convictions is, in this author's view, inequitable. See, e.g., People v. Clapp, 67 Cal. App. 2d 197, 153 P.2d 758 (1944); People v. District Court, 191 Colo. 558, 554 P.2d 1105 (1976) (en banc); People v. Morlock, 234 Mich. 683, 209 N.W. 110 (1926). Contra, Neal v. Commonwealth, 221 Ky. 239, 298 S.W. 704 (1927); Williams v. State, 125 Miss. 347, 87 So. 672 (1921); Staniforth v. State, 24 Ohio App. 208, 156 N.E. 924 (1927); State v. Alexander, 10 Wash. App. 942 , 521 P.2d 57 (1974). It is unfair to treat a person who ultimately stands convicted of only one crime as a multiple offender. Although some logistical problems may arise, particularly when the second sentence has already been completed at the time the conviction is set aside, the nost reasonable procedure would be to treat the defendant as a recidivist initially, see Perrin v. State, 198 Kan. $650,654,426$ P.2d 39, 42 (1969), but to resentence him nunc pro tunc once the conviction is set aside. As noted above, for statutes punishing the denial of a conviction not yct set aside, the subsequent setting aside of the conviction is irrelevant. Accordingly, in that situation the recidivist statute is properly applied.

91. Note, Pretrial Diversion from the Criminal Process, 83 YALE L.J. 827, 827 (1974). See generally E. Lemert, INSTEAD OF COURT: DIVERSION IN JUVENILE Justice (1971), McPike, Criminal Diversion in the Federal System: A Congressional Examination, 42 FED. Prosation 10 (Dec. 1978); Note, Pretrial Diversion from the Criminal Process: Some Constitutional Considerations, 50 IND. L.J. 783 (1975). See also the testimony and exhibits included in The Community Supervision and Services Act: Hearings on S. 798 Before the Subcomm. on National Penitentiaries of the Senate Comm on the Judiciary, 93d Cong., 1st Sess. 336-534 (1973) [hereinafter cited as Hearings on S.798]. Since the establishnent of the two pioneer diversion programs, Manhattan's "Court Employment Project" and Washington, D.C.'s "Project Crossroads," approximately 50 jurisdictions have begun similar projects. See Nordheimer, Pretrial Diversion Held Helpful in Cutting Crime, N.Y. Tines, Sept. 21, 1973, at 46, col. 1.

92. See, eg., Internal U.S. Attorney's Office Memorandum on Pre-trial Diversion Guidelines for Washington, D.C.'s “Project Crossroads” (on file at Duke University Law Library). 
the hallmark of the process is prosecutorial flexibility and discretion. ${ }^{93}$ Invariably, however, there are two limitations upon that discretion. ${ }^{94}$ First, diversion is ordinarily available only to offenders charged with committing a specific category of crime or, if broadly available, is designed to eliminate certain classes of offender. ${ }^{95}$ Second, only first offenders or persons with a limited criminal record are eligible. ${ }^{96}$

If a diversion program admits only first offenders, ${ }^{97}$ should an FYCA offender who has had his conviction set aside be eligible? The offender would argue that he is technically a first offender and therefore ehigible. Those seeking to deny him admission would counter that the new charge proves he is unrehabilitated and therefore unworthy of a second chance.

Which view is better depends on the relevance of an unvacated conviction to the diversion decision. A prior conviction bears negatively on the defendant's request for admission to pretrial diversion in four ways. First, the new offense apparently does not represent an isolated mistake; the defendant cannot claim that he deserves just one chance to prove his law-abiding nature, because he has already coin-

93. See, e.g., Note, supra note 91, 83 YALE L.J. at 828 ("Diversion represents a discretionary exercise and is often used synonymously with discretion").

A diversion program may take a variety of forms. It may be based on prosecutorial discretion, see, e.g., National Committee for Children and Youth, Project Crossroads as Pretrlal Intervention: A Program Evaluation (1970); Vera Institute of Justice, Pretrial Intervention: The Manhattan Court Employment Project: Final Report (1972), administrative guidelines, or administered jointly by the prosecution and the courts as a form of probation before judgment. See, e.g., 21 U.S.C. \& 844(b) (1976); 27 MD. ANN. CodE § 641 (1955) (subsequently amended in other respects at 27 MD. CRIMES AND PUNISHMENTS CODE ANN. \& 641 (1980 Supp.). All scheines are designed to unburden the courts, give defendants an opportunity to overcome what may be an isolated error in judgment, and provide rehabilitative services which would be more costly if provided through incarceration. Note, Pretrial Diversion from the Criminal Process: Some Constitutional Considerations, 50 IND. L.J. 783, 784-85 (1975). While some programs require the defendant to undergo a prejudgment rehabilitation program, others acknowledge that some defendants may have committed an isolated error in judgment and need no rehabilitation. These extract a minimal measure of punishment to avoid letting the defendant off scot-free and then provide for dismissal of the charges.

94. Note, supra note 91, 83 Y ALE L.J. at 832-44.

95. Some diversion programs, for example, are restricted to persons charged with drug crimes or otherwise shown to have a connection with narcotics use. See Robertson, Pretrial Diversion of Drug Offenders: A Statutory Approach, 52 B.U.L. Rev. 335 (1972); Note, Addict Diversion: An Alternative Approach for the Criminal System, 60 GEO. L.J. 667 (1972). Others, such as Washington, D.C.'s Project Crossroads, exclude persons charged with illegal firearm possession from their purview. See Internal U.S. Attorney's Office Memorandum on Pre-trial Diversion Guidelines, supra note 92 , at 5 .

96. See Note, supra note 91, 83 YALE L.J. at 832-33.

97. Project Crossroads, although somewhat flexible in the application of its guidelines, is one example of such a program. See NATIONAL COMmitteE for Children and Youth, supra note 93. 
mitted a prior crime..$^{98}$ Second, the defendant's failure to profit from his first contact with the criminal justice system marks him as unresponsive to rehabilitation and therefore less likely than others to benefit from the diversion program. Third, the defendant has already demonstrated that he tends to recidivism. He is thus the type of offender prosecutors want to imcarcerate, rather than assist. Finally, admitting him to a diversion program will not affect his prior criminal record, and he will therefore not be able to benefit from one of the principal goals of diversion, the avoidance of a criminal record altogether.

Most of these negative inferences suggest that a set-aside FYCA conviction, like any other conviction, should still render an offender meligible for pretrial diversion. The FYCA offender has already been given his second chance through the FYCA; if he abused that second chance by committing a new offense, nothing in the legislative history of the FYCA or the case law suggests that lie should be entitled to a third. Similarly, like the adult second offender, he has demonstrated a tendency to recidivism. The order setting aside his conviction does not alter the fact that he has committed a crime in the past. Prosecutors may justifiably fear that this defendant is not a good risk to avoid future contact with the criminal justice system. ${ }^{99}$

98. Before a defendant will be considered for admission into a diversion program, he must admit that he committed the offense charged. This requirement is based on the notion that it would be unfair to impose sanctions on an innocent defendant or to treat him as one in need of rehabilitative services. But because it often seems more unfair to deny benefits to one who reasonably claims his innocence while extending them to one who admits his guilh prosecutors waive this requirement fairly frequently. Waiver is especially common among prosecutors who view diversion primarily as a means of unburdering the criminal justice system of an overwhelming trial calendar and as a means of settling weak cases where the defendant does proclain innocence. See Note, Restructuring the Plea Bargain, 82 YALE L.J. 286, 292-97 (1972) ("When his evidence is weak, the prosecutor will propose generous bargaining terms to overcome the defendant's inclimation to go to trial").

99. An alternative method of analyzing the FYCA in this context is to consider the Act itself as establishing a form of diversion program. Like such programs, the FYCA permits the young offender to undergo a prescribed program of rehabilitation that leaves him with an arrest record, see Doe v. Webster, 606 F.2d 1226, 1230-31 (D.C. Cir. 1979); United States v. McMains, 540 F.2d 387 (8th Cir. 1976), but no record of conviction. An analogous "diversion program" for drug offenders is authorized in 21 U.S.C. $\$ 844$ (b) (1976). Under this program ehgible offenders suspected of narcotics use may plead guilty to the offense charged and postpone sentencing. If they then refram from drug use for three months, the courts permit withdrawal of the guilty plea and the prosecutor dismisses the charges. Unsuccessful defendants are sentenced pursuant to their pleas.

What is instructive about this analysis is that offenders who have previously participated in a diversion program, even successfully, are generally inehigible for renewed admission. This practice is based on the same reasoring that applies to offenders with set-aside convictions; they had one chance to make good, but lost it. Furthermore, this analysis demonstrates that a prosecutor who considers a set-aside conviction without automatically denying diversion does not contravene the legislative intent to eliminate a conviction's stigma. As with the denial of cntry to a diversion 
Only with respect to rehabilitation does the setting aside of a conviction bear any relevance. Although a judge or a parole authority setting aside a conviction has already determined that the offender should be deemed rehabilitated, the FYCA conteinplates that the rehabilitative process may need to continue after the termination of a sentence. ${ }^{100}$ The applicant for pretrial diversion can therefore reasonably claim that he would benefit froin further rehabilitation through the diversion program.

On balance, however, a prosecutor would be acting well within his discretion in relying on a set-aside conviction to deny admission to a diversion program. The congressional desire to free the offender from the taint of his prior conviction does not bar the prosecutor's consideration of the conviction in this context. ${ }^{101}$ Because a set-aside conviction differs from a normal one in that it puts upon the defendant soine stamp of rehabilitation, however, the prosecutor should not automatically give it the full effect of an ordinary conviction. He should exercise his discretion, taking into account the nature of the crime and the defendant's record of conduct simce the prior conviction. He should not be bound by a rigid rule. ${ }^{102}$

\section{Sentencing.}

No court has considered whether judges may rely on a set-aside

program because of a prior diversion opportunity, a denial of entry because of a set-aside conviction is actually based on the defendant's having received and wasted a "chance"; it is not based on the prior offense itself. The prosecutor does not attach a stigma to the conviction nor treat the defendant differeutly from other unusual conviction-free defendants (e.g., those having completed a diversion program).

100. See text accompanying notes $30-31$ supra.

101. Diversion programs are ordinarily considered matters governed by unfettered prosecutorial discretion. Even if a prosecutor could not lawfully consider a set-aside conviction, a defeudant would be hard pressed to find a procedure to challenge the prosecutor for having done so. One commentator, however, argues that because diversion programs are a form of plea bargaining and encroach significantly upon what would otherwise involve the court's sentencing discretion, judges should exercise their supervisory authority over the diversionary process. See Note, supra note 91, 83 YALE L.J. at 839-40, 843-44. Bases for such judicial activity inay be imbedded in statutory language, see, e.g., N.J.R. CRIM. P. 3:28(a), (b); PA. R. CRIM. P. 175, 178, or may be inherent in the court's supervisory power over the judicial system and the hitigants before it.

102. The analysis in this section apphes as well to those diversion programs in which one prior conviction does not eliminate a defendant from ehigibility. All diversion guidelines include among their criteria the nunber and types of convictions the applicant has had in the past. See NATIONAL COMMITIEE FOR ChILDREN AND YouTH, supra note 93, at 1; Note, supra note 91, 83 YALE L.J. at 828-29. In any systen the set-aside conviction should be considered as a standing conviction, except that the prosecutor should exercise particular flexibility with regard to it, giving special consideration to the defendant's record of susceptibility to supervision and rehabilitation. 
conviction in imposing a sentence for a subsequent offense. ${ }^{103}$ While judges are generally entitled to consider any fact in imposing a sentence, ${ }^{104}$ policy and practical considerations suggest the contrary should be the rule wliere set-aside convictions are concerned.

Congress lias provided by statute that a sentencing court inust have broad access to information concerning a defendant's prior history: "No limitation sliall be placed on the information concerning the background, character, and conduct of a person convicted of an offense which a court of the United States nay receive and consider for the purpose of imposing an appropriate sentence." 105 Even prior to the enactinent of this statute, the courts typically considered even the reniotest of facts, including a judge's subjective belief tlrat a defendant had perjured himself, ${ }^{106}$ uncharged criminal acts, ${ }^{107}$ cliarges that resulted in

103. The reason for this void of judicial authority is self-evident. Courts rarely explain the sentences they impose, and thus no basis exists upon which to appeal an improper sentence. A young offender therefore cannot establish that a judge has rehed on the vacated conviction. Many commentators have attacked the judicial practice of unsubstantiated sentencing precisely because this practice results in unwarranted sentence disparities and sentences based on improper consideratious. See generally Berkowitz, The Constitutional Requirement for a Written Statement of Reasons and Facis in Support of the Sentencing Decision: A Due Process Proposal, 60 lowa L. Rev. 205 (1974); Coburn, Disparity in Sentences and Appellate Review of Sentencing, 25 RuTOERs L. REv. 207 (1971); Korbakes, Criminal Sentencing Should the "Judge's Sound Discretion" Be Explained?, 59 JUDICATURE 184 (1975); Taparauskas, An Argument for Confrontation at Sentencing: Bringing the Offender into the Sentencing Process, 8 CuM. L. Rev. 402 (1977).

In United States v. Klusinan, 607 F.2d 1331 (10th Cir. 1979), the court considered a similar issue. The defendant's conviction had becn set aside. He was subsequently found guilty of a new crime and appeared for sentencing before the same judge who had set aside his earlier conviction. The judge remembered the defendant. The defendant appealed his sentence, claiming the sentencing court had improperly considered his set-aside conviction. The Court of Appeals for the Tenth Circuit affirmed the sentence without deciding whcther, in circumstances where a sentencing judge has no personal knowledge of a set-aside conviction, the judge may still take that conviction into account. The court noted that "there exists a public interest factor which must be considered. The trial judge has a broad discretion in designing the sentence. He should not be required to erase from his memory a relevant fact about which he has personal knowlcdge." Id. at 1334. By failing to order the trial judge's recusal, the appellate court implied that a set-aside conviction may be considered by any sentencing judge.

104. See, eg., United States v. Grayson, 438 U.S. 41 (1978); Williams v. New York, 337 U.S. 241 (1949). For discussions of Grayson and the cases leading up to it, see Note, Defendant's Right to Protection from Prior Uncounseled Convictions, 1973 WASH. U.L.Q. 196; 83 Dick. L. REv. 367 (1979); 28 Emory L.J. 159 (1979); 7 Fordham URe. L.J. 441 (1979); 12 J. Mar. J. Prac. \& Proc. 407 (1979); see also Note, A Hidden Issue of Sentencing: Burdens of Proof for Disputed Allegations in Presentence Reports, 66 Gвo. L.J. 1515 (1978).

105. 18 U.S.C. $\& 3577$ (1976).

106. United States v. Grayson, 438 U.S. 41, $52-55$ (1978).

107. United States v. Bass, 535 F.2d I 10, 118-21 (D.C. Cir. 1976); United States v. Crowe, 516 F.2d 824, 826 (4th Cir. 1975); United States v. Strauss, 443 F.2d 986, 990-91 (1st Cir.), cert. denied, 404 U.S. 851 (1971); $c$. United States v. Metz, 470 F.2d 1140 (3d Cir. 1972) (other indictments pending), cert. denied, 411 U.S. 919 (1973). 
dismissals or acquittals, ${ }^{108}$ and convictions that were reversed on appeal. ${ }^{109}$

The nature of FYCA convictions provides several potent reasons why courts should be permitted to consider them in sentencing. First, because they do represent convictions, they are far more reliable than uncharged criminal acts or charges resultimg in dismissals or acquittals. ${ }^{110}$ If courts may consider those factors in evaluating a defendant's character, they should arguably be allowed to consider vacated convictions as well. Second, sentencing courts evaluate, among other things, whether a defendant is susceptible to rehabilitation and what rehabilitative services he needs. It is certainly relevant to these determinations to know what form of sentence the defendant has served in the past, what form of rehabilitation programs he participated $\mathrm{m}$, and what effect they have had upon him. Finally, the sentencing court must safeguard the community. If the defendant tends to recidivisin, as the commission of a second offense indicates, the court should be able to take steps to prevent future victims from suffering injury. ${ }^{111}$ Thus, in fixing sentences, courts have usually considered even expunged juvenile convictions to which they have accidentally gained access. ${ }^{112}$

There are, however, countervailing considerations. If Congress truly intended to free a young offender from the consequences of his conviction, ${ }^{113}$ the conviction should not be considered in sentencing. Treatment as a second offender in sentencing, like treatment under a recidivist statute, is the qunitessential stigma or effect of a prior conviction. Furtherinore, if a set-aside conviction may be used in sentencing, the setting-aside becomes no different from a pardon: both prevent future civil disabilities from accruing to the initial conviction, but no 1nore. Yet Congress without question intended an effect greater than

108. E.g., Williams v. New York, 337 U.S. 241, 244 (1949); United States v. Cardi, 519 F.2d 309, 313-15 (7th Cir. 1975); United States v. Sweig, 454 F.2d 181, 183-84 (2d Cir. 1972); United States v. Doyle, 348 F.2d 715, 721 (2d Cir.), cert. denied, 382 U.S. 843 (1965).

109. E.g., United States v. Atkins, 480 F.2d 1223, 1224 (9th Cir. 1973).

110. There are some guidelines limiting the discretion of sentencing courts. See, e.g., $12 \mathrm{~J}$. Mar. J. PraC. \& Proc. 407, 409-10 n.15 (1979). The most important of these limitations is that the court may not rest its decision on unreliable or potentially unreliable information. In United States v. Tucker, 404 U.S. 443 (1972), for example, the Supreme Court remanded a case for resentencing because the sentencing court relied on two convictions later found to be unconstitutional. The touchstone of Tucker was the Court's determination that the convictions relied upon by the sentencing court were prima facie unreliable. Set-aside convictions do not suffer from this disability.

111. Similar reasoning is used in cormection with diversion programs, see text accompanying notes 91-102 supra, namely, that a defendant is entitled to one chance to avoid punishment, but not to a second.

112. See, eg., Neely v. Quatsoe, 317 F. Supp. 40, 42 (E.D. Wis. 1970).

113. See text accompanying notes 35-39 supra. 
that of a pardon. ${ }^{114}$ Finally, although the new offense may deinonstrate that a youth has "slipped back" on his road to rehabilitation, he must have been thought to have made some progress toward rehabilitation initially, or his conviction would not have been set aside. If a sentencing judge is permitted to consider the set-aside conviction, he will as a practical matter find it nearly inpossible to distinguish the setaside conviction from a standing conviction. The earlier determination under the FYCA of the defendant's rehabilitation will therefore lose all effect, and he will be deprived of the reward Congress intended ${ }^{115}$ in providing for the setting aside of the conviction. 116

It is not inconsistent to forbid judges to consider set-aside convictions in sentencing but to permit such consideration by prosecutors rendering diversion decisions. ${ }^{117}$ A FYCA offender denied diversion is not receiving treatment harsher than a citizen who has not been convicted of a crime; he is merely being denied a form of discretionary grace that would permit him to avoid the consequences of the first crime he has committed. He has received his one opportunity at grace; other offenders may receive theirs through diversion. If a set-aside conviction is used in sentencing, however, the FYCA offender is penalized. $\mathrm{He}$ is treated as a second offender, while the ordinary first offender and the first offender who has once completed diversion are treated as if they have a clean record, even though diversion may have been far simpler to complete than the FYCA probation or parole. ${ }^{118}$ The FYCA's "free" or "second" chance inelts away under these circumstances. Enforcing a rule that leaves the FYCA offender in the same

114. See text accompanying notes 59-66 supra.

115. See text accompanying note 29 supra.

116. Some courts take the view that the congressional grant of a benefit is a conditional one that the young offender forfeits if he commits another crime. In Smearman v. United States, 279 F. Supp. 134, 136 (W.D. Pa. 1968), the court used this rationale to justify imposing a six-year sentence under the FYCA, 18 U.S.C. $\$ 5010(G)$ (1976), where the maximum regular adult sentence was five years. See also Brisco v. United States, 246 F. Supp. 818 (D. Del. 1965), affd, 368 F.2d 214 (3d Cir. 1966). Although this argument has some surface appeal, it lacks support in the legislative history. Both the sponsors and the opponents of the bill agreed that the legislation was for treatment and rehabilitation alone-not for punishment. See text accompanying notes 12-31 supra. Nothing im the Act suggests that its benefits could be forfeited by an offender's bad behavior after completion of his sentence. Cf. Hearings on S. 1114 and S. 2609, supra note 15, at 117 (letter of the Hon. Charles C. Wyche (W.D.S.C.)) (suggesting to the contrary, that "a boy who makes one mistake should be permanently forgiven that mistake if his subsequent conduct indicates that he has changed his behavior").

117. See text accompanying notes 97-102 supra.

118. Because diversion programs are designed in part to reheve a court's calendar congestion, those admitted to the program customarily undergo a short (e.g., three inonths) program of rehabilitation. Probation imposed under 18 U.S.C. § 5010(a) (1976), may last indefinitely and usually lasts six months to two years in relatively minor cases. A sentence under section 5010(b) continues for six years, and a sentence under section 5010(c) inay be longer. 
position as a first offender for purposes of sentencing but not for purposes of admission to a diversion program is therefore sensible.

In practice, courts can easily justify permitting or not permitting consideration of set-aside convictions in sentencing. After the Supreme Court's recent decision in United States $v$. Grayson ${ }^{119}$ that a court may consider its behef that the defendant lied on the stand in fixing his sentence, courts ignoring such convictions inay be in the minority. Nevertheless, if Congress's enactment of section 5021 is to have any ineaning, ${ }^{120}$ the sounder approach would be to ignore the conviction. ${ }^{121}$ On balance, the risk of according a youth more favorable sentencing consideration than he may deserve is a fair price to pay for effectuating the purpose of the FYCA. ${ }^{122}$

\section{Impeachment of Witnesses.}

A FYCA offender may on occasion be called to testify in court, either as a witness on his own behalf or as a witness for a third party. One disability ordinarily attaching to a criminal conviction is that the offender inay be impeached with his conviction. ${ }^{123}$ The law is unfortunately unclear on the issue of whether such impeachinent will be per1mitted where a set-aside conviction is concerned. ${ }^{124}$

The confusion stems primarily from the imprecise language of

119. 438 U.S. 41 (1978).

120. It is a common view that recent decisions interpreting the FYCA have rendered it a charade. See, e.g., Harnsberger, supra note 5, at 415-17; Ritz, supra note 5, at 777-79. Coinpare the similar views concerning other systems limiting the effect of convictions found in Booth, supro note 8 , at $162-66$.

121. This article recommends giving effect to a set-aside conviction for some purposes other than sentencing, but only where the legislative purpose of the Act would not be disserved. See, e.g., text accompanying notes 73-102 supra and notes 123-48 infra. The article at no time recommends ignoring the setting aside of a conviction, as wonld occur in the sentencing sitnation, but instead supports the use of the conviction only when the use would not flatly contravene the purposes of the setting-aside provision.

122. Problems may occur if the sentencing judge learns of a set-aside conviction mdependently of the sentencing process. See, e.g., United States v. Klusinan, 607 F.2d 1331, 1333 (10th Cir. 1979), discussed in note 103 supra. Recusal is a possibility here. Another is a requirement that the judge give a short stateinent of reasons for the sentence he imposes, and that he explicitly disavow on the record any cousideration of the set-aside conviction.

123. The basis for impeachment with a prior conviction is the notion that the prior conduct bears on the witness's readiness to perjure himself. See, e.g., $3 \mathrm{~J}$. WeInSTEIN \& M. BERGER, WEINSTEIN'S EVIDENCE \ 609 [02], at 609-55 to 62 ("Rationale for Allowing Impeachment by Convictions; Alternative Solutions") (1978). There is always the danger, however, that the jury will consider a defendant-witness's prior conviction not for purposes of evaluating crcdibility, but instead as evidence of a criminal 1neutality. See the authorities cited at note 145 infra.

124. Thus far, this article lias considered only situations in which a FYCA offender lias connmitted a new crime and thereby disappointed Congress's expectation of rehabilitation. $\mathbf{I}$. the situations that follow, that is not the case, and a court inust deem the offender fully rehabilit ted in deciding whether to allow mention or use of the set-aside conviction. 
Luck v. United States, ${ }^{125}$ the first case to address the issue. In Luck a juvenile defendant was sentenced under the FYCA after the juvenile courts waived jurisdiction of his case pursuant to statute. Two years later he was charged with a new crime. At trial he took the stand on his own behalf, and the court perimitted the Government to impeach him with his prior conviction. Luck appealed, claiming the trial court erred in failing to exclude the prior conviction as a juvenile adjudication, which by statute was not admissible. ${ }^{126}$ The court of appeals rejected this claim, holding:

We find no clear purpose on the part of Congress to withdraw from the reach of this last mentioned [impeachment] statute convictions of juveniles in the district court as adults following upon waivers of jurisdiction by the Juvenile Court. Just as more severe sentencing provisions are available for those who are waived, so does conviction entail the consequences that the government may seek to use it to attack availability in a later proceeding. ${ }^{127}$

The court held, however, that trial courts should consider the witness's status as a youth at the time of the conviction in determining whether to permit impeachment by the conviction. 128

The ambiguity of the Luck opimion arises from its omissions. Nowhere in the opimion can one discern whether the defendant's earher conviction was ever set aside. The defendant never raised any specific issue concerning the use of set-aside convictions, nor did the court inake clear whether it was confining its decision to defendants who were eligible for juvenile court jurisdiction. Furthermore, the court at no time drew any distinction between FYCA offenders as party or nonparty witnesses, a distinction that might well mandate different results. ${ }^{129}$

Soine courts have treated Luck as a leading case; ${ }^{130}$ others have sidestepped it (and subsequent cases relying upon it) and have reached

125. 348 F.2d 763 (D.C. Cir. 1965). See Ritz, supra note 5, at 759 n.81 ("The extent to whieh FYCA convictions that have been set aside may be used for impeachment . . . has not been resolved").

126. 348 F.2d at 766-67 \& n.4; see D.C. CODE ANN. \& 16-2308(d) (1961 \& Supp. V 1960) (later superceded by D.C. CODE ANN. \& 16-2318 (1973)).

127. 348 F.2d at 766 .

128. Id. at 769 .

129. The clearest discussion of the issue of impeachment with a set-aside conviction is found in 3 J. WeINSTEIN \& M. BERGER, WEINSTEIN's EvidENCE I 609 [04], at 609-83 ("Effect of Pardons, Annulments, or Certificates of Rehabilitation") (1978). Even this treatment of the question fails to consider whether party witnesses should be trcated differently from nonparty witnesses.

130. See, e.g., United States v. Canniff, 521 F.2d 565 (2d Cir. 1975), cert. denied, 423 U.S. 1059 (1976). The court of appeals in Canniff stated,

By way of contrast, a person subject to the federal Youth Corrections Act, 18 U.S.C.

$\S \S 5005-26$, is convicted of a crime and then is eligible for the alternative sentence pro- 
the opposite result without authority for their position. ${ }^{131}$ Only a few courts have recognized that $L u c k$ fails to address squarely the question whether a set-aside conviction can be used for impeachment. ${ }^{132}$

Should a set-aside conviction be admissible to impeach a witness? Consider first the nonparty witness. Weighing in favor of admissibility is the point that if commission of a crime tends to show that a person would perjure himself on the stand, the additional fact that the offender was eighteen to twenty-six years of age at the time of the crime hardly reverses that tendency. In addition, the rights of a litigant include the privilege of introducing all probative evidence of bias or untruth on the part of the opposing party's witness.

Yet a certificate of discharge is awarded to a FYCA offender only upon a finding of rehabilitation. Unlike punishment under recidivist statutes, admission to pretrial diversion programs, or sentencing, ${ }^{133} \mathrm{im}$ peachment would be of an offender who has committed no new crimes to cast doubt on his rehabilitation. If his character is truly reformed, it would be inappropriate to allow a jury to consider the conviction in assessing his character and credibility. ${ }^{134}$

vided in that Act. . . . The record of this conviction is not kept sealed and it may be used to attack credibility in a later proceeding.

521 F.2d at 569 n.2. Cf. Umited States v. Ashley, 569 F.2d 975, 979 (5th Cir.) (failure to allow the defendant to impeach a Government witness with a set-aside conviction is error, though harmless), cert. denied, 439 U.S. 853 (1978).

131. See, e.g., United States v. Trejo-Zambrano, 582 F.2d 460, 464 (9th Cir.), cert. denied, 439 U.S. 1005 (1978); State v. Pacheco, 121 Ariz. 88, 91, 588 P.2d 830, 833 (1978).

132. Sce, e.g., Brown v. Umited States, 370 F.2d 242, 245 n.10 (D.C. Cir. 1966). Courts generally agree that a conviction not yet set aside nay be used to attack credibility. That, of course, is the minimum ruling of Luck itself. See also United States v. Trejo-Zambrano, 582 F.2d 460, 465 (9th Cir.), cert. denied, 439 U.S. 1005 (1978); United States v. Ashley, 569 F.2d 975, 978 (5th Cir.), cert. denied, 439 U.S. 853 (1978). But the court may consider the possibility that a conviction will be set aside in exercising its discretion to admit or exclude the conviction. Brown v. United States, 370 F.2d at 245 n. 10.

133. See text accoinpanying notes 73-122 supra.

134. Compare the effect of a pardon. A pardon nuay be granted on the basis of subsequent proof of innocence or rehabilitation, or for imdependent reasons, such as a particular act of bravery. From these facts, the leading authority on pardons draws the following conclusions:

If the pardon was granted because the prisoner had pohtical influence, or was a unodel prisouer, or behaved bravely in a prison fire, the pardon should not affect his credibility at all. The damage to his credibility . . . is not a legal consequence of the conviction; the conviction is merely evidence that he is untrustworthy, a fact not wiped out by the pardon.

Weiliofen, supra note 62, 88 U. PA. L. Rev. at 182 . He has also stated: "The only sound rule is that pardon for innocence blots out not only punishment but also guilt; other pardons relieve from further punishment and all other legal consequences of the conviction, but do not affect the fact of guilt." Weiliofen, supra note 62, 12 Rocky MTN. L. REv. at 112. See also State v. Zinn, 562 S.W.2d 784 (Mo. App. 1978). Based on this analysis, FED. R. Evid. 609(c) provides that a pardoned conviction, or a conviction followed by a certificate of rehabilitation, as authorized by the FYCA, is admissible if the pardon or certificate does not stent froni a finding of innocenee or rehabilitation, but is not admissible if such a finding has been made. Judge Weinstein concludes 
Other elements to consider include the possibility of stigmatizing the witness and the effect of the admission on the litigation. A nonparty witness stands to lose little from the impeachment. ${ }^{135}$ It may be somewhat embarrassing for him to testify, but that problem is inherent in all court appearances. To the extent the jury does not believe him, it is the litigant offering his testimony who suffers; the witness will not endure any effects of a "stigma" or "taimt" resulting from the conviction. Thus the courts should not give undue weight to the harn to a nonparty witness in evaluating whether a set-aside conviction should be used for impeachment. ${ }^{136}$

The determination of the effect that the introduction of a nonparty witness's set-aside conviction will have on the litigation is best suited to a case-by-case analysis. The Luck approach of balancing the relevance of the crime to credibility, the remoteness in time of the conviction, the degree to which the witness's credibility is an issue, ${ }^{137}$ and the impor-

from this analogy of the setting aside of a conviction to a pardon that set-aside convictions are by definition imadmissible in federal proceedings. See $3 \mathrm{~J}$. WEINSTEIN \& M. BERGER, WEINSTEIN's EvIDENCE I 609 [04], at 609-80.5 to 84 (1978) ("Effect of Pardons, Annulments, or Certificates of Rehabilitation").

135. Professor Gough argues that an offender called as a witness and faced with the prospect of being impeached with a prior set-aside conviction "would be strongly tempted to deny that he has seen anything [and] would do whatever he could to avoid the witness stand and the possibility of public exposure and humiliation." Gough, supra note 8, at 159. This problem arises with most witnesses, regardless of whether they stand to be impeached by a prior conviction. Professor Gough exaggerates the effect impeachment would have on a witness. Ordinarily, all that the impeaching party may do is ask a single question in a neutral form such as "Are you the same [John Doe] who was convicted in [1965] of [armed robbery]?" While perhaps somewhat embarrassing, this impeachment will not typically have a stigmatizing effect on a nonparty witness.

When impeachment by the prior conviction may prove unusually embarrassing-if, for example, it is remote in time, the witness is a respected citizen, and the trial will be visible-the stigma and taint of the conviction may resurface. Under these circumstances, a court would be justified in closing the courtroom to the public, a process which the Supreme Court has recently held to be constitutionally permissible in unusual circumstances. See Gannett Co. v. Pasquale, 443 U.S. 368, 378 (1979). See also Richmond Newspapers, Inc. v. Virginia, 100 S. Ct. 2814, 2830 (1980) (the presumption against closed trials can only be overcoine in unusual circumstances and for specified reasons).

136. One can argue that because the nonparty witness can be compelled to testify, he should be given greater deference on the witness stand and should not be impeachable by his prior conviction. But becanse the very purpose of compulsory process is to enable litigants to introduce relevant and probative evidence, the witness's preferenee not to give testimony or release information about himself is not a valid ground for excluding the evidence.

137. If, for example, the witness is an expert witness, no perjury is likely to arise and the setaside conviction should not be considered. A contrary rule would, in fact, have a harmful effect that the FYCA did not intend. For example, an expert who rehies on being able to testify as part of his profession (e.g., an imsurance adjuster) can ill afford to be impeaehed by a set-aside conviction; few attorneys would risk engaging his testimony and services, for fear that the jury would hold the conviction against him. This is a form of employment stigma that the setting-aside process is desigued to eliminate. See text accompanying notes 155-70 infra. 
tance of the witness's testimony is appropriate in this situation. ${ }^{138}$ Added to the balance, however, should be the conduct of the witness between the time of his discharge from his conviction and the date of his testimony; that conduct will be a fair indicator of whether the rehabilitation has so taken root that rehance on the prior conviction would be untrustworthy. ${ }^{139}$

As a theoretical matter, the case-by-case approach is the soundest; it grants juries access to set-aside convictions when they have some probative value, but denies access when that value is outweighed by the need to avoid subjecting FYCA offenders to undue stigma from the convictions. But although a hard-and-fast rule excluding the conviction is uncalled for, a court should not hesitate to exercise its discretion to prevent impeachment if rehabilitation has stripped the set-aside conviction of probative value. ${ }^{140}$ Furthermore, when the impeachment is permitted, a court should instruct the jury that the conviction has been set aside and should provide a brief explanation of that process. ${ }^{141}$

Different considerations apply when the witness is a party. The disclosure of a party witness's prior conviction can dramatically affect the outcoine for that party, especially if he is a criminal defendant. Re-

138. For a discussion of these considerations, see United States v. Hayes, 553 F.2d 824, 826-28 (2d Cir.), cert. denied, 434 U.S. 867 (1977); United States v. Mahone, 537 F.2d 922, 929 (7th Cir.), cert. denied, 429 U.S. 1025 (1976). See also 3 J. Weinstern \& M. Berger, Weinstein's EviDENCE If 609 [03], at 609-62 to 72 ("The Luck Discretionary Approach").

139. Since Luck was decided, the District of Columbia has amended the statute that, the Luck court found, gave it discretion to admit or exclude convictions for impeachment purposes. The new statute, D.C. CODE ANN. \& 14-305 (1973), makes it mandatory to admit most convictions less than 10 years old. See Project, supra note 62, at 1038-45, for a compilation of various state impeachment statutes. A nondiscretionary statute should not apply to set-aside convictions, however, because those convictions are no longer "standing convictions," and because they reflect an offender's rehabilitation and hence are less reliable imdicators of a lack of credibility.

140. Although some courts take the view that impeachment with a set-aside conviction will have little effect upon a jury one way or the other, see, e.g., Umited States v. Ashley, 569 F.2d 975 (5th Cir.) (the failure to allow impeachment with a set-aside conviction is "harmless error"), cert. denied, 439 U.S. 853 (1978); People v. Robinson, 1 Cal. App. 3d 555, 81 Cal. Rptr. 666 (1969) (the admission of a set-aside conviction is "harmless error"), cert. denied, 398 U.S. 913 (1970), the questionable probative value of a set-aside conviction renders it mappropriate for automatic and unqualified submission to the jury.

141. The Model Penal Code states that all convictions, including set-aside convictions and pardons based on rehabilitation, should be admissible to impeach, but that the opposing party nay rehabilitate the witness by introducing the certificate of rehabilitation or order setting aside the conviction. Model Penal CODE \& 306.6(3)(b)(e) (Proposed Official Draft 1962). Many jurisdictions permit a witness impeached by a prior conviction that has not been set aside to make a brief statement in explanation or mitigation of the offense. See $3 \mathrm{~J}$. Weinstern \& M. BERGER, WeInSTEIN's EvidenCE If 609 [03a], at 609-80.2 ("Rule 609(a) As Applied by the Courts") (1978); Project, supra note 62, at $1043-45$. 
gardless of the type of cautionary instruction the court employs, ${ }^{142}$ there is a substantial risk that the jury will consider the conviction as evidence of guilt or undeserving eharacter, rather than merely as evidence bearing on his credibility. ${ }^{143}$ The threat of impeachment 1nay induce the party not to take the stand, even where it would be appropriate for him to do so. ${ }^{144}$ To be sure, the same risks obtain whether a party witness's conviction has been set aside or not. But the pohicy of the FYCA adds additional weight to the already heavy criticism ${ }^{145}$ of impeachment by a prior standing conviction. To extend the practice to set-aside convictions, which are of questionable relevance even on the issue of credibility, ${ }^{146}$ would magnify the dangers. At least one court has adopted a fixed rule precluding the use of set-aside convictions to impeach criminal defendants. ${ }^{147}$ This appears to be the better rule where civil litigants are concerned as well. ${ }^{148}$

142. See Note, The Limiting Instruction-Its Effectiveness and Effect, 51 MinN. L. Rev. 264, 281-88 (1966).

143. See, e.g., H. Kalven \& H. Zeisel, The American Jury 160 (1966). The authors' empirical study shows that, other things being equal, juries acquit defendants without a criminal record in $65 \%$ of all cases, but acquit only $38 \%$ of all defendants with a record.

144. See, e.g., Griswold, The Long View, 51 A.B.A.J. 1017, 1021 (1965); Notc, To Take the Stand or Not to Take the Stand: The Dilemma of the Defendant with a Criminal Record, 4 Colum. J.L. \& Soc. Prob. 215 (Jnly 1968).

145. See, e.g., Spector, Impcachment Through Past Convictions: A Time for Reform, 18 DePaUL L. Rev. 1 (1968); Note, Impeaching the Accused By His Prior Crimes-A New Approach to an Old Problem, 19 Hastings L. Rev. 919 (1968); Note, Constitutional Problems Inherent in the Admissibility of Prior Record Conviction Evidence for the Purpose of Impeaching the Credibility of the Defendant Witness, 37 U. CIN. L. REv. 168 (1968).

146. See text accoinpanying notes 133-34 supra.

147. United States v. Trejo-Zambrano, 582 F.2d 460, 464 (9th Cir.), cert. denied, 439 U.S. 1005 (1978). Contra, United States v. Canniff, 521 F.2d 565, 569 n.2 (2d Cir. 1975) (dictum), cerf. denied, 423 U.S. 1059 (1976).

California has adopted a rule that a conviction set aside pursuant to California law may not be used to impeach a witness unless that witness is a criminal defendant. See Cal. Evid. CoDE \$ 788(d) (West 1966). The prior law in California was to the contrary. See People v. Mackey, 58 Cal. App. 123, 208 P. 135 (1922); Note, Penal Rchabilitation Benefits Curtailed, 2 STaN. L. Rev. 221 (1949). A possible basis for the current statute is the view, not shared by most jurisdictions, see 3A J. Wigmore, Evidence $\$ 987$ (Chadbourn rev. Supp. 1980); C. MCCormick's HANDBOOK OF THE LAW OF EvidenCE $\$ 43$ (2d ed. E. Cleary ed. Supp. 1978), that a jury should be permitted to consider a prior bad act as evidence of guilt, even though the witness has subsequently proved himself to be rehabilitated. This logic is precisely what courts interpreting the FYCA have tried to foreclose in holding that the setting aside of a conviction is designed to free the offender froun the taint of the prior conviction. See note 29 supra.

148. A more difficult question arises when an offender becomes a criminal defendant before the term of his first sentence has expired. The only court that has directly considered whether to permit impeachment by the use of a prior conviction in this situation held that the mere possibility the conviction would be set aside was not, by itself, enough to render the conviction madmissiblc. Brown v. United States, 370 F.2d 242, 245 n.10 (D.C. Cir. 1966).

If such a conviction is ruled admissible, and the offender is in fact innocent of the second offense, he is likely to suffer a double penalty. The chances of his second conviction will be in- 


\section{E. Civil Disabilities.}

Civil disabilities resulting froin criminal convictions inay stein froin a variety of sources. ${ }^{149}$ They inay be statutory. Some states take from convicted felons such privileges as voting, ${ }^{150}$ holding public office, ${ }^{151}$ testifying im court, ${ }^{152}$ serving as jurors, ${ }^{153}$ or actimg as a legal entity. ${ }^{154}$ Other disabilities attach when someone im the private sector learns of a conviction and consequently refuses the offender a benefit such as employment. ${ }^{155}$ Finally, administrative agencies may imterpret their statutory authority or establish their own rules so as to penalize offenders, as im proceedings concerning deportation ${ }^{156}$ or professional licensing. 157

With respect to these types of disability, the FYCA's legislative history shows that Congress was concerned first and foremost with eliminating the stigma the conviction would impose upon the young offender; it wanted to give him a "second chance" to be treated as an ordinary citizen"158 - to wipe out the "blot on his record" that would otherwise "cause him great harm when he applie[d] for a position im

creased, see notes 142-46 supra and accompanying text, and a second conviction in turn will probably be sufficient evidence of a lack of rehabilitation that his first conviction will not be set aside. The heavy criticism by commentators of admitting even standing convictions, see notes 142-47 supra and accompanying text, and Congress's general policy of affording a young defendant a full opportunity for rehabilitation argue for disallowing impeachment in this circumstance.

149. These consequences are identified and discussed in full in Project, supra note 62.

150. E.g., Alaska Stat. \& 15.05.030 (1980); ARIz. Rev. Stat. ANN. \& 16-101(5) (1975); Mo. ANN. STAT. § 561.024(1)(2) (Vernon 1979); Wash. Const. art. 6, § 3.

151. E.g., Ky. Const. \& 150; Fla. Stat. ANN. \& 114.01(1)(j) (Supp. 1980); Mo. ANN. Stat. $\S 561.021 .3$ (Vernon 1979).

152. E.g., ALA. CoDE § 12-21-162 (1975).

153. E.g., Ky. Stat. Rev. ANN. 29A.080(2)(E) (Bobbs-Merrill 1980); Mo. ANN. Stat. $\S 561.026(3)$ (Vernon 1979).

154. See, e.g., D.C. Code ANN. \& 20-351 (1973).

155. See, eg., the studies discussed in Gough, supra note 8, at 153-55.

156. E.g., Rehman v. Immigration \& Naturalization Serv., 544 F.2d 71 (2d Cir. 1976); Mestre Morera v. Immigration \& Naturalizaton Serv., 462 F.2d 1030 (Ist Cir. 1972); Briscoe v. United States, 391 F.2d 984 (D.C. Cir. 1968); Hernandez-Valensuela v. Rosenberg, 304 F.2d 639 (9th Cir. 1962).

157. Professor Gough refers to an unpublished survey that identifies 59 occupations requiring a license from which an offender may be barred. Gough, supra note 8, at 156. These occupations range from yacht selling to the practice of law. See, e.g., In re Florida Bd. of Bar Examiners, 361 So. 2d 424 (Fla. 1978); Appeal of Estes, 580 P.2d 977 (Okla. 1978).

158. See text accompanying notes 35-39 supra. See also United States v. Glasgow, 389 F. Supp. 217,224 (D.D.C. 1975). The Supreme Court has held that the removal of civil disabilities is the quid pro quo for the possibility that a young offender charged with a crime with a maximum penalty of less than six years may nevertheless be sentenced to a six-year term of incarceration under 18 U.S.C. \& 5010(b). See Dorszynski v. United States, 418 U.S. 424, 429 n.6 (1974). See also Durst v. United States, 434 U.S. 542 (1978), and authorities cited therein. These two cases are discussed at length in Ritz, supra note 5. 
later years."159 Nevertheless, the limited number of cases that have been decided concerning the civil disabilities mentioned above ${ }^{160}$ reveal not only isolated practical problems unanswered by the legislative history, but more significantly demonstrate that courts facing the problems are disinclined to give full effect to Congress's intent.

One of the first such cases was Fite v. Retail Credit Co. ${ }^{161}$ Even though Fite's conviction had been set aside, a local credit reporting agency obtained the court records of the conviction and passed the information along to its custoiners. As a result, Fite lost one job and had difficulty obtaining another. He sued to restram the agency from disseminating the information. The district court, in an opinion giving little heed to the purposes of the FYCA, denied rehef. Relying on the incontrovertible but irrelevant conclusion that history cannot be rewritten, the court held that Fite's convicton "reflected a fact, i.e., the admission of a theft. That fact could be of interest to a potential employer without regard to the technical legal consequences of it."162

By ignoring the purpose of the FYCA, the court avoided the most vexing issue before it: notwithstanding Congress's desire to minimize the stigma of a conviction, particularly when the offender seeks employment, does a court have the authority to police the actions of private parties who rely on truthful information lawfully in their possession? The answer-had the court addressed the issue-should have been no. Congress recognized that, even if a conviction is fully set aside, employers may find out about the conviction and rely on it. ${ }^{163}$ For those circumstances, Congress provided no relief except the issuance of a certificate of discharge, which the offender could use to explain the convietion and his subsequent rehabilitation.

That does not end what should have been the Fite court's inquiry. A court can take steps to ensure that the congressional purpose is fully effectuated. It can limit the access of private parties to the set-aside conviction records, mstruct law-enforcement authorities to respond negatively to inquiries about thein, ${ }^{164}$ and make clear to the offender

159. Hearings on S. 1114 and S. 2609, supra note 15, at 117 (letter of the Hon. Charles Wyche (W.D.S.C.)). See also Note, supra note 5, at 559-62.

160. See, e.g., Briscoe v. United States, 391 F.2d 984 (D.C. Cir. 1968) (deportation); Hernandez-Valensuela v. Rosenberg, 304 F.2d 639 (9th Cir. 1962) (deportation); In re Florida Bd. of Bar Examiners, 361 So. 2d 424 (Fla. 1978) (bar admission); Appeal of Estes, 580 P.2d 977 (Okla. 1978) (bar admission). See generally text accompanying notes 173-77 infra.

161. 386 F. Supp. 1045 (D. Mont. 1975), affd, 537 F.2d 384 (9th Cir. 1976).

162. $386 \mathrm{~F}$. Supp. at 1048.

163. See notes $44-46$ supra and accompanying text.

164. The courts in Doe v. Webster, 606 F.2d 1226, 1244 (D.C. Cir. 1979), and United States v. Henderson, 482 F. Supp. 234 (D.N.J. 1979), issued such orders. See text accompanying note 58 supra. 
that he may answer a prospective employer's imquiry of whether he has ever been convicted of a crime by saying "No." 165 Through these approaches, the Fite court could have afforded some rehef, while preserving employers' rights to use information lawfully in their possession.

A similar problem has surfaced with state-imposed disabilities such as the removal of the right to carry a firearm or to serve on a jury. The question arises whether an offender should be required to acknowledge a set-aside conviction when asked (for example, on a firearm-registration requirement questionnaire or a jury panel) if he has been convicted of a crime. The answer is clearly no: otherwise the setting-aside process has no effect. The few courts addressing this issue seein to have agreed. One court noted that

if this Court holds that a young adult whose conviction has been set aside does not have the same rights to possess firearms as other citizens, [its ruling] would, in effect, state that the youth has not been rehabilitated, that he cannot be trusted and that he does not deserve a second chance. ${ }^{166}$

By implication, the court authorized the FYCA offender to deny his conviction when applying for permission to carry a firearm ${ }^{167}$ and in other similar situations.

Courts have given a different answer to whether an applicant for admission to a local bar association inust disclose a set-aside conviction. In Appeal of Estes ${ }^{168}$ and In re Florida Board of Bar Examin$e r s,{ }^{169}$ two state supreme courts overruled the automatic exclusion of FYCA offenders based solely on their set-aside convictions. Nevertheless, both courts perumitted the bar examiners to consider "the commission of [the] crime by [the] applicant in the overall ineasurement of character and fitness and weighing it in connection with other evidence

165. See notes 36-38 supra and accompanying text. See also Saperstem, supra note 5; Kutcher, Looking at the Law, 42 FED. Probation 60, 61 (Sept. 1978). Not only should the youth be authorized to answer in this fashion, but he should also be inade aware that he inay do so. A specific authorization to that effect in the certificate of discharge given to him wonld ensure his awareness.

In Doe v. Webster, 606 F.2d 1226, 1244 (D.C. Cir. 1979), the court authorized a FYCA offender to "reply in the negative to any and all questions concerning his former conviction" (footnote omitted). But see MODel PeNal CODE § 306.6(3)(f) (Proposed Official Draft 1962) ("An order [vacating a conviction] . . . does not justify a defendant stating that he has not been convicted of a crime, unless he also calls attention to the order").

166. United States v. Fryer, 402 F. Supp. 831,837 (N.D. Ohio 1975), aff'd, 545 F.2d 11 (6th Cir. 1976).

167. A similar issue arises when an offender on a jury panel is asked to fill out a form listing his convictions. In Schaefer, supra note 6, at 33-34, the author considers the federal Juror Qualification Questiomraire designed to implement the Jury Selection Act of 1968, 28 U.S.C. \& 1865(b)(5) (1976), and concludes that FYCA offenders may legally deny any conviction.

168. 580 P.2d 977 (Okla. 1978).

169. 361 So. $2 d 424$ (Fla. 1978). 
of character."170 These rulings are questionable. Once the proper authority has determined that a FYCA offender is rehabilitated, bar examiners have no more reason to consider past convictions than do sellers of firearms or employers. Exclusion from professional status is precisely the type of stigma the 1950 Congress that enacted the FYCA considered and disapproved.

Several administrative decisions have addressed the right of the government to deport immigrants on the basis of set-aside convictions. After some litigation of the issue, ${ }^{171}$ the Immigration and Naturalization Service determined that set-aside convictions could not serve as a basis for deportation. ${ }^{172}$ That determination failed to resolve the problem for most offenders, because deportation proceedings ordmarily commence shortly after a conviction, before the conviction can be set aside. Practically speaking then, the issue is whether deportation may be based on a conviction that has not yet been set aside, but that may be in the future.

Two courts have considered the issue, ${ }^{173}$ both concluding that the "possibility of future grace in no respect affects the present fact of guilt"174 and thus that a standing conviction, whether susceptible of eventually being set aside or not, may be used as grounds for deportation. Neither court, however, analyzed the problem nor offered support for its decision, and on close mspection the result appears to be wrong. Because the early cases and the Immigration and Naturalizaton Service recognized that set-aside convictions may not be considered im a deportation proceeding, courts facing the issue must start from the premise that Congress wanted to provide relief from deportation once an offender proves himself rehabilitated. Yet that premise means nothing if the offender is not given an opportunity to prove himself.

This conclusion is supported by the decision of the Court of Appeals for the First Circuit in Mestre Morera v. Immigration and Naturalization Service. ${ }^{175}$ Mestre Morera was sentenced under the FYCA and a deportation decree was issued promptly. Mestre Morera appealed,

170. Id. at 426 .

171. See, e.g., Mestre Morera v. Immigration \& Naturalization Serv., 462 F.2d 1030, 1032 (1st Cir. 1972), in which the court stated, "We cannot imagine a more complete deprivation of a second chance than deportation. We are unable to presume that Congress, without any reference to such an intent, ineant in section 5021 to provide for setting aside a conviction for some purposes but not for others."

172. Rehman v. Immigration \& Naturalization Serv., 544 F.2d 71, 74 (2d Cir. 1976).

173. Briscoe v. United States, 391 F.2d 984, 987-88 (D.C. Cir. 1968); Hernandez-Valensuela v. Rosenberg, 304 F.2d 639 (9th Cir. 1962).

174. Hernandez-Valensuela v. Rosenberg, 304 F.2d at 640.

175. 462 F.2d 1030 (1st Cir. 1972). 
forcing a stay of the deportation proceeding. By the time the case reached the court of appeals, the conviction had been set aside. Accordingly, the court vacated the deportation decree.

The present state of the law encourages such litigation. By pursuing appeals and engaging in other delaying tactics, an offender who can afford to do so may postpone deportation long enough to have his conviction set aside. It is grossly unfair for a court to predicate a resultdeportation or no deportation - on a youth's ability to engage in dilatory litigation. When, as in deportation proceedings, it costs little to postpone an administrative decision until the sentence is complete, ${ }^{176}$ the government should do so. ${ }^{177}$ In this way, the congressional purpose to eliminate all civil disabilities for the rehabilitated offender is best effectuated.

\section{CONCLUSION}

A young offender's conviction, set aside under section 5021 of the Federal Youth Corrections Act, may yet be called up for use in a variety of circumstances. Because the legislative history of the Act gives clear guidance in only a few of these circumstances, courts faced with interpreting the "setting aside" process have floundered and reached inconsistent results.

For some circumstances Congress's intention is unambiguous. For example, the imposition of civil disabilities on an offender is clearly forbidden. Congress expressly intended that the setting aside of a conviction remove the stain on the offender's record and allow him the full exercise of a citizen's civil rights. Denying a FYCA offender the right to carry a firearm, to sit on a jury, or to become a ineinber of the bar are precisely the types of disabilities that a court should not permit.

176. The Immigration and Naturalization Service is required by statute to postpone deportation proceedings until an incarcerated offender is released. 8 U.S.C. $\$ 1252$ (h) (1976). See 1A C. Gordon \& H. Rosenfield, 1A ImMIGRATION LAW \& Procedure § 5.16c at 5-192.3-5-194 (rev. 1981). Thus, when a defendant is sentenced to a term of imprisonment under 18 U.S.C. $\$$ 5010(b) or (c) (1976), the expense of incarceration is not saved by deportation. Accordingly, the only costs of delaying deportation until a FYCA sentence is complete are the costs of probation or parole supervision.

177. There are other situations in which the courts have refused to stay deportation based on an illegal alien's anticipation of a reprieve froun an outside source such as a private bill of Congress or the granting of a special visa application. See, e.g., De Figueroa v. Immigration \& Naturalization Serv., 501 F.2d 191, 192-93 (7th Cir. 1974); Armstrong v. Immigration \& Naturalization Serv., 445 F.2d 1395, 1396 (9th Cir. 1971); Bowes v. District Director of the United States Immigration \& Naturalization Serv., 443 F.2d 30, 31 (9th Cir. 1971); United States ex rel. Fen v. Esperdy, 423 F.2d 6, 8 (2d Cir. 1970); Siu Fung Luk v. Rosenberg, 409 F.2d 555 (9th Cir.), cert. dismissed, 396 U.S. 801 (1969). In contrast, the possibilitiy of grace by means of a set-aside conviction is not a "purely theoretical possibility," see Briscoe v. United States, 391 F.2d 984, 987-88 (D.C. Cir. 1968), but a frequent occurrence. See Harnsberger, supra note 5, at 396. 
Other uses of set-aside convictions similarly contravene Congress's policy of giving young offenders a second chance. A sentencing judge, for example, should not consider a prior set-aside conviction to be relevant to an offender's sentence for a second offense. Nor should a FYCA offender be prosecuted under a recidivist statute for a subsquent offense. Clearly, to so ignore the setting aside of a conviction is to ignore the Congressionally mandated distinction between set aside and standing convictions.

Yet just as clearly Congress did not intend that the record of a conviction be totally destroyed or forever sealed for all purposes. Some discretionary uses of a set-aside conviction do not conflict with the congressional intent. The impeachment of a nonparty witness at trial and the selection of an offender for pretrial diversion are two examples of permissible uses. Impeachment, although embarrassing, does not ordinarily deny the nonparty witness any civil rights or prejudice his future prospects. Pretrial diversion programs are not appropriate even for every first time offender; having already had one chance to avoid a criminal record, a FYCA offender cannot complain when his set-aside conviction is given soine, though not conclusive, weight in the decision about him.

This article has considered only a few contexts in which a set-aside conviction may surface. They show that when one party seeks to einphasize the conviction and the young offender objects, the courts are forced to weigh countervailing considerations. In the past, judges have ruled either without thought ${ }^{178}$ or by overlooking the importance of the benefits Congress conferred upon young offenders in $1950 .{ }^{179}$ The specific examples discussed above deinonstrate that the sounder approach would be to articulate a careful balance of the underlying legislative purposes and strong societal interests that compete against thein.

178. E.g., Fite v. Retail Credit Co., 386 F. Supp. 1045 (D. Mont. 1975) (a FYCA conviction should be freely available to a credit agency's customers to use in denying einployment), aff $d, 537$ F.2d 384 (9th Cir. 1976); In re Florida Bd. of Bar Examiners, 361 So. 2d 424 (Fla. 1978) (bar examiners may consider an applicant's set-aside conviction to deny his admission to the bar); Appeal of Estes, 580 P.2d 977 (Okla. 1978).

179. E.g., United States v. Ashley, 569 F.2d 975 (5th Cir.), cert. denied, 439 U.S. 853 (1978); Hernandez-Valensuela v. Rosenberg, 304 F.2d 639 (9th Cir. 1962) (the possibility of a set-aside order is of no importance to a deportation decision); Smearman v. United States, 279 F. Supp. 134, 136 (W.D. Pa. 1968) (a FYCA sentence may become punitive rather than rehabilitative in purpose); People v. Robinson, 1 Cal. App. 3d 555, 81 Cal. Rptr. 666 (1969) (the improper use of a set-aside conviction is harmless error). 